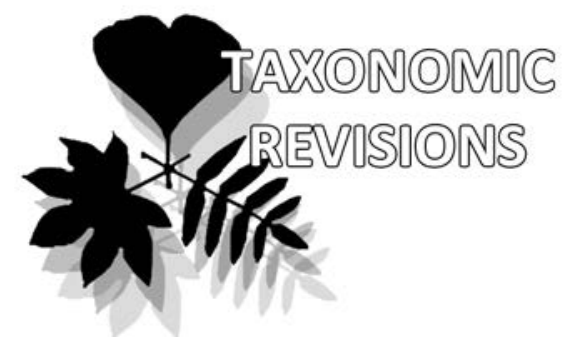

\title{
A review of Radulaceae (Marchantiophyta) in the Russian Far East
}

\author{
Vadim A. Bakalin* \& Ksenia G. Klimova
}

Vadim A. Bakalin*

e-mail:vabakalin@gmail.com

Ksenia G. Klimova

e-mail: ksenia.g.klimova@mail.ru

Botanical Garden-Institute FEB RAS Vladivostok, Russia

*corresponding author

Manuscript received: 14.11.2019

Review completed: 07.04.2020

Accepted for publication: 20.05.2020

Published online: 09.06.2020

\begin{abstract}
A B S T R A C T
Radulaceae are revised for the Russian Far East. The occurrence of eight species is confirmed; the previous reports of two taxa based on misidentification are excluded from the flora. The paper provides: 1) the identification key to Radula known in the Russian Far East, 2) morphological descriptions and illustrations based on the specimens collected there and 3) descriptions of ecology and distribution of treated taxa.
\end{abstract}

K e y w o r d s : Radulaceae, Radula, Hepaticae, taxonomy, the Russian Far East, East Asia

\section{P E 3 Ю M E}

Бакалин В.А., КАимова К.Г. Обзор семейства Radulaceae (Marchantiophyta) на российском Аамьнем Востоке. Семейство Radulaceae ревизовано Аля российского Аальнего Востока. ПодтвержАено распространение 8 вилов, ранние указание на распространение еще Авух видов ошибочны. Работа содержит: 1) ключ Аля определения Radula известных на российском Аальнем Востоке, 2) морфологические описания и иллюстрации, основанные на изучении образцов из российского Аальнего Востока 3) описание экологии и распространения таксонов известных в регионе.

КАючевые слова: Radulaceae, Radula, печеночники, таксономия, российский $\Delta$ альний Восток, Восточная Азия

\section{N T RO D U C T IO N}

Radulaceae is the monogenetic family counting ca. 200 extant taxa, although some of them have unclear status (Devos 2011, Frye \& Stech 2009, Söderström et al. 2016). The family (and therefore the genus Radula) is characterized by prostrate plant growth, Radula-type branching, rhizoids originating from inflated area (composed by smaller cells) in ventral lobe, conduplicate bilobed leaves with ventral lobe smaller, dorsal lobe completely covering ventral lobe and possesses rounded to (rarely) acute apex, underleaves absent (even as slime papillae), perianth strongly dorsiventrally compressed (not evident so when submature sporophytes are inside of the perianth), massive short seta, bistratose capsule wall, bispiral elaters. Some taxa have large thallose protonema. Vegetative distribution is by produced occasionally multicellular gemmae or fragile leaves.

In the phylogenetic sense the Radulaceae form highly isolated lineage (Devos et al. 2011, Frey \& Stech 2009) and similarly distinctly isolated morphologically that the confusion with other genera looks hardly probable. The main attention to distinguish Radula from other families with conduplicate bilobed (or trilobed, with third lobe reduced to stylus), like Lejeuneaceae, Jubulaceae, Porellaceae and Frullaniaceae, should be paid to the total absence of underleaves, even as slime papillae and distribution of rhizoids in the inflated area near the base of ventral leaf lobe. The recent robust advance in the understanding of Radula phylogeny and classification was due to efforts by Devos et al. (2011). The latter work was the first one testing the infrageneric classification of the genus using molecular-genetic methods. As authors wrote (Devos et al. 2011: 1629) "At present, the classification scheme is therefore based almost only on molecular features". The latter was due to certain incongruence of morphology-based classification to that produced in cited paper. Authors showed the great distance of subg. Cladoradula Spruce (to that Radula auriculata of our flora is belonging) from other bulk of taxa. Further subg. Dactyloradula Devos, M.A.M. Renner, Gradst., A.J. Shaw \& Vanderp. is split from the remained bulk (the latter subgenus includes Radula brunnea only). Moreover Devos et al. (2011) showed rapid morphological diversification in the genus in early stages of its evolution.

Radulaceae were poorly studied in the Russian Far East. The well known among Russian bryologists Schljakov's manual of hepatics of the northern USSR (Schljakov 1982) includes data on three species of the genus: circumpolar Radula complanata, Mega-Beringian R. prolifera and European - Eastern North American R. lindenbergiana Gottsche ex C. Hartm. Radula lindenbergiana was recorded for the Russian Far East in the past (e.g. by Gambaryan 1984), however, it was only due to misidentification of $R$. constricta.

Appears the first record of Radula for the Russian Far East was that of $R$. complanata for continental mainland (Amur River basin) by Lindberg (1872). Then Kamimura (1939) recorded an obvious rarity - R. brunnea - for Kaibato (Moneron) Island. The next report of Radula was published in the middle of 20-th century by Korotkevich (1952). The robust advance in the knowledge of Radula 
taxonomic diversity in the Russian Far East was due to Asian monographer of this genus Dr. Kohsaku Yamada (NICH). Approximately in 1985 Dr. S.K. Gambaryan, the first Far-Eastern professional hepaticologist, has sent to Yamada 12 specimens of Radula where he found 4 species. These records were published by Yamada (1986), including R. auriculata new for the USSR, R. obtusiloba - new for continental mainland of the Russian Far East and shown that $R$. constricta replaces $R$. lindenbergiana in the Russian Far East. Potemkin (2003) recorded R. japonica as new for the Russia and then Bakalin and Klimova reported R. fauriana in Ellis et al. (2017).

Within last 30 years, many new data on distribution of Radula in the Russian Far East were collected. These data were summarized in the distribution dot maps of hepatics in the Russian Far East (Bakalin 2010), a book that is partly out of date now. Until present there were no reliable sources to identify Radula in the Russian Far East and to find the summarized data on taxa distribution and ecology in this huge area (ca. 3 millions $\mathrm{km}^{2}$ ). Certainly, Yamada's (1979) monograph on Radula in Asia was very helpful to identify Radula specimens here. However, it is quite difficult to use the monograph as the 'identification key' for inexperienced users because it contains 61 species and quite complex keys (firstly to subgenera, then to sections, series and only then to species). Moreover, the latter work does not provide the distribution in the Russian Far East and describes ecology of taxa in very general traits.

The main goal of the present work was to provide 1) the identification key to Radula known in the Russian Far East, 2) morphological description and illustrations based on the specimens collected here and 3) descriptions of ecology and distribution of taxa in the Russian Far East. The present study is based on examination of over 250 specimens of Radula collected in the Russian Far East and now kept in VBGI (with VLA liverwort collection incorporated). The information from all specimen labels was input into online accessible herbarium database (http:// botsad.ru/herbarium/) maintained by VBGI. Besides, the coordinates of the each specimen were summarized into the table and used to construct point dot maps (based entirely on studied specimens) by the specially prepared software available in http://botsad.ru/hepaticae/maps/. All figures were prepared from moist specimens 're-soaked' from herbarium using Olympus SZX10 with drawing tube Olympus SZX-DA.

\section{TAXONOMIC TREATMENT}

Radula Dumort., Commentat. Bot. (Dumortier): 112, 1822 (Dumortier 1822) nom. conserv.

Eight species of Radula are confirmed in the Russian Far East. They may be keyed out as following.

\section{Identification key to Radula taxa known in the Russian Far East}

1. Plants with amentulose branches (short branches not or slightly longer than dorsal leaf lobe of the main axis, with leaf lobes of that branch nearly subequal), never on woody substrates

1. Plants without amentulose branches, although sometimes with small-leaved branches those however are much longer than dorsal leaf lobe of the main axis and leaves in smallleaved branches are distinctly unequal (rarely subequal in the older sector of the branch, but in that case plants growing on tree bark only)

2. Plants dark brown, temperate East Asian species (in our area the southernmost islands only), dioicous

Radula brunnea

2. Plants yellowish greenish, pale colored, soft, arcticmontane Mega-Beringian, autoicous or dioicous

R. prolifera

3. Leaf ventral lobe covering stem completely and sometimes going beyond the stem edge, stem in cross section with welldeveloped 2-3-layered cortex ......

R. auriculata

3. Leaf ventral lobe covers $1 / 4-1 / 3(-1 / 2)$ of stem width; well-developed cortex is absent in stem cross section, although one laver (outer cells of the stem) sometimes have

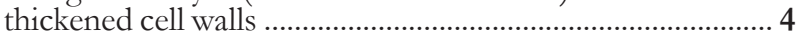

4. Plants dioicous, yellowish greenish in color, rarely with perianths, always with abundant gemmae along leaf margin

R. constricta

4. Plants dioicous (then greenish brownish to brownish, glossy) or monoicous (then yellowish greenish, not glossy), gemmae virtually absent (rarely may be found in invariable fertilized paroicous R. complanata) ............................................. 5

5. Plants brownish and greenish-brownish, glossy, dioicous

5. Plants greenish yellowish to yellowish, not glossy, monoicous (paroicous or autoicous) ………………………………... 7

6. Gynoecia terminal on main axis, stem in cross section commonly less 6(-7) cells high ............................. R. japonica

6. Gynoecia terminal on short lateral branches, stem in cross section commonly more (7-) 8 cells high ........ $\boldsymbol{R}$. obtusiloba

7. Plants paroicous or autoicous, with small-leaved branches present, trigones in the middle of leaf dorsal lobe moderate in size, on woody (bark of trees) substrates ....... $\boldsymbol{R}$. fauriana

7. Plants paroicous, small-leaves branches absent, trigones in the middle part of dorsal leaf lobe small to very small, on various substrates, including also bark of trees

R. complanata

Radula auriculata Steph., Bull. Herb. Boiss. 5: 105, 1897.

Figs 1:1, 2; 2: A, B; 3: A.

Description. Plants more or less rigid, slightly glossy, deep green to brownish green, loosely attached to the substrate or commonly ascending, $0.9-2.1 \mathrm{~mm}$ wide and 20$60 \mathrm{~mm}$ long, branches commonly narrower than the main axis and becoming depauperate, $0.3-0.9 \mathrm{~mm}$ wide. Stem deep brown, rigid, regularly pinnately branched, rarely with sparse branches of the second order; cross section of welldeveloped stem slightly transversely elliptic, (100-) 130-220 $\times(125-) 175-260 \mu \mathrm{m},(7-) 10-13$ cells high with distinct thick-walled cortex cells in 2-3 layers, composed by unequally to subequally thickened cell walls with moderate in size, concave trigones, cells $12-14 \mu \mathrm{m}$ in diameter, becoming more thin-walled inward (walls obscurely thickened, never thin), with moderate in size, concave trigones, cells varying in diameter from 12 to $25 \mu \mathrm{m}$. Rhizoids virtually absent in our material. Leaf dorsal lobes imbricate to contiguous, obliquely inserted, in dorsal side insertion line arcuate, obliquely oriented, slightly convex, but with distinctly turned to ventral side lobe apex, when flattened in the slide obliquely ovate to somewhat falcate, $1.0-1.2 \times 0.8-1.0 \mathrm{~mm}$. Keel relatively short, $1 / 4-1 / 3$ of dorsal lobe length, arched. Ventral leaf lobe nearly plane, obliquely ovate to 
1

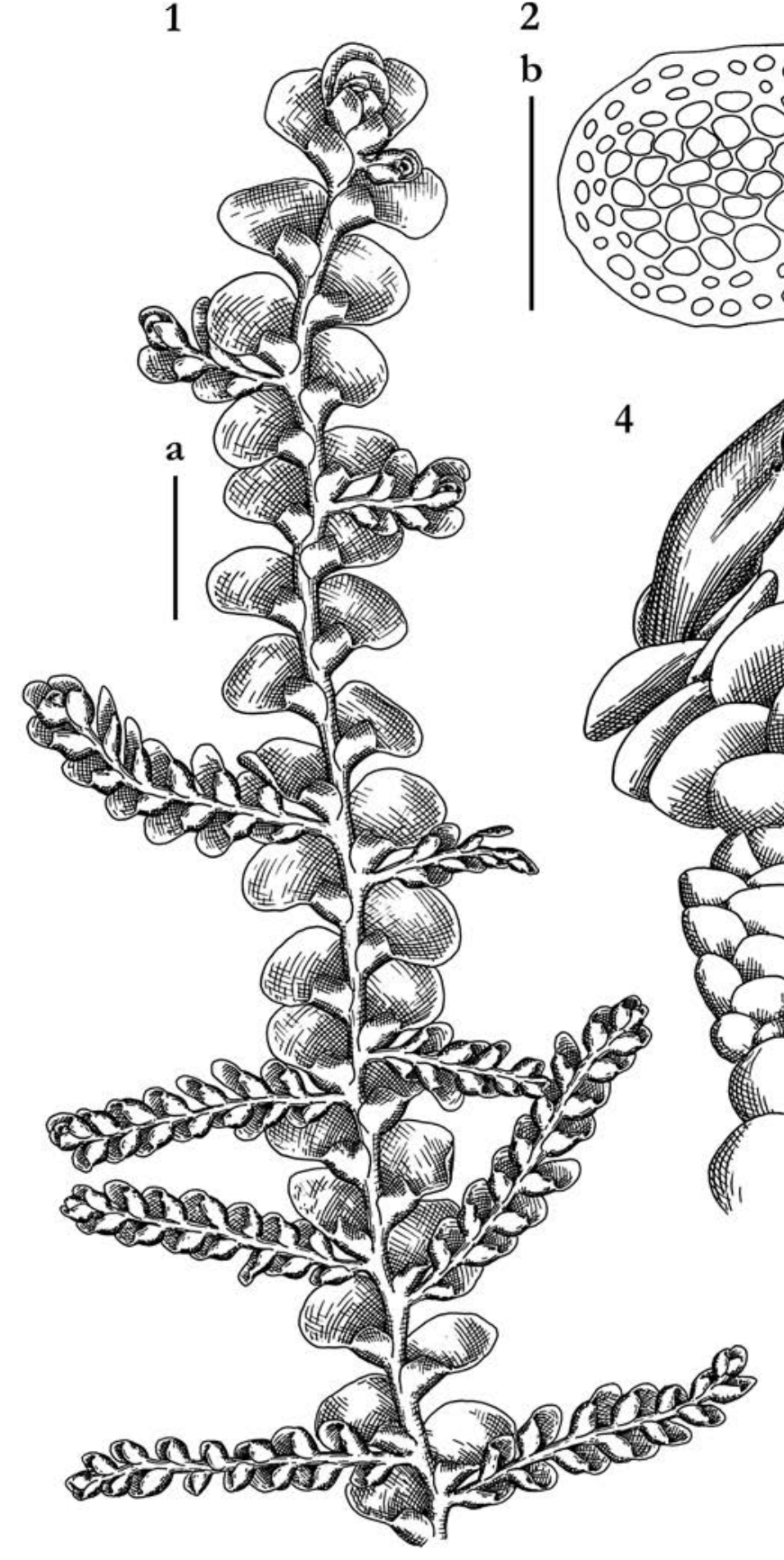

3

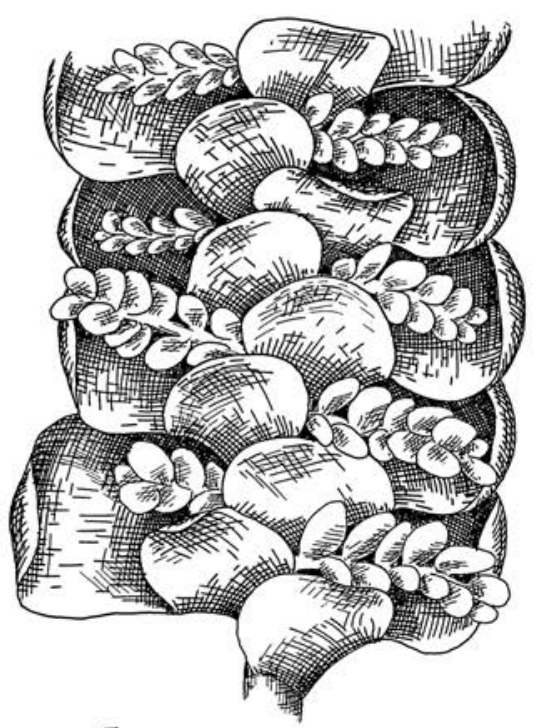

5

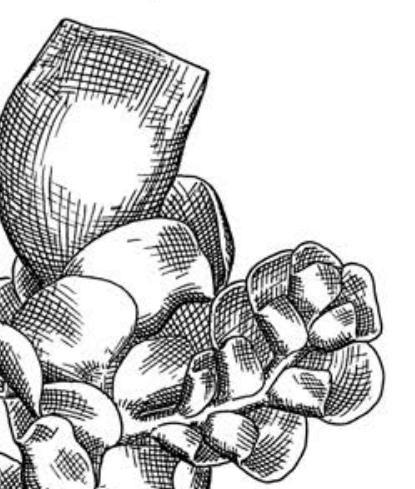

Figure 1 Radula auriculata (Steph.): 1 - plant habit, ventral view; 2 - stem cross section. $\boldsymbol{R}$. brunnea Steph.: 3 - plant habit, fragment, ventral view. $\boldsymbol{R}$. complanata (L.) Dumort.: 4 - plant habit with perianth, dorsal view; 5 - plant habit with perianth, ventral view. Scales: a - $1 \mathrm{~mm}$, for 1 ; $\mathrm{b}-100 \mu \mathrm{m}$, for 2; c- $1 \mathrm{~mm}$, for 3; d - $1 \mathrm{~mm}$, for 4, 5 (1, 2 from Prim-108-2-19; 3 from K-42-34-07; 4, 5 from P-72-18-05, VBGI)

ovate-rhomboidal, $0.3-0.5 \times 0.2-0.4 \mathrm{~mm}$, transversely inserted, covering stem width completely and sometimes going farther beyond stem edge, although in smaller forms covering only $0.5-1.0$ of stem width, lobe apex rounded to somewhat attenuate (never obtuse or acute). Cells in dorsal lobe middle subisodiametric to shortly oblong, 15-25 × 15$20 \mu \mathrm{m}$, thin- to obscurely thick-walled, trigones moderate to small, triangular to slightly concave or convex, cuticle smooth; cells along dorsal lobe margin 12-22 $\mu \mathrm{m}$, external wall thickened, other walls thin, trigones moderate in size to small, concave. Dioicous. Androecia at lateral branches, intercalary or terminal (when branch dies above androecia), divided by 1-3 pairs of sterile leaves between main axis and androecial bracts, with 3-7 pairs of bracts.

Comment. Commonly easily identifying taxon due to well-developed cortex, ventral leaf lobe covering stem completely and, even, going beyond of the stem edge and dorsal leaf lobe distinctly turned to ventral side. The only difficulties may occur when poorly developed plants are in hand. These plants characterized by leaf ventral lobe covering stem only partly (as a rule, not less than $2 / 3$ of the stem width) and thinner stem with poor cortex. Such modifications may be mistaken with robust forms of Radula obtusiloba from which R. auriculata differs in peculiar brownish (sometimes even 

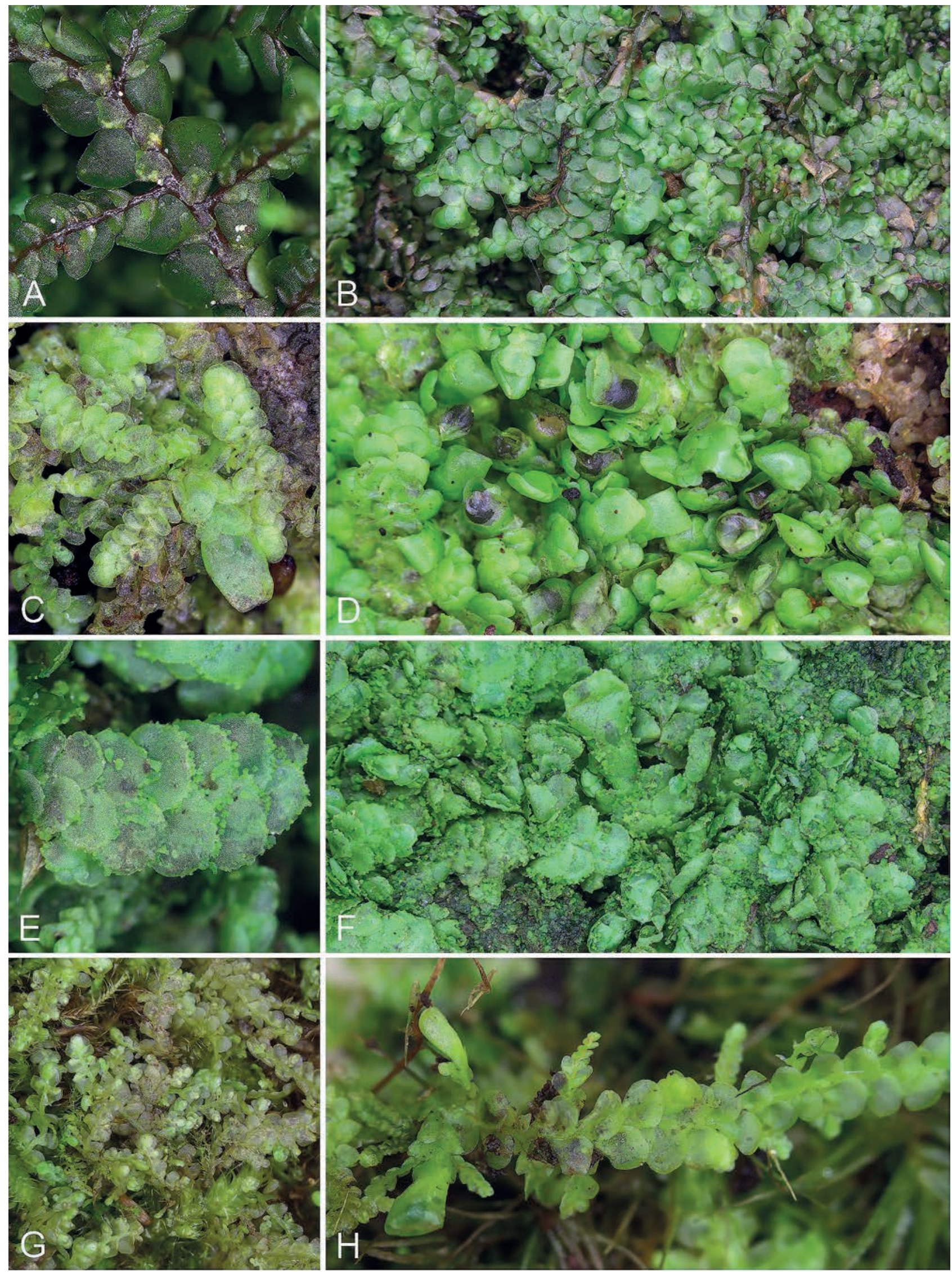

Figure 2 Radula auriculata (Steph.): A - branch, fragment, ventral view (Prim-108-2-19, VBGI); B - general habit (P-34-21-14, VBGI). R. complanata (L.) Dumort.: C - perianthous branch (K-34-11-18, VBGI); D - general habit, plants with perianths (S-45-8-16, VBGI). $\boldsymbol{R}$. constricta Steph.: E - branch with gemmae; F - general habit, plants with gemmae and perianth (all from S-29-2-17, VBGI). $\boldsymbol{R}$. fauriana Steph.: G - general habit (S-45-30-16, VBGI); H - perianthous branch (K-70-39-15, VBGI) 

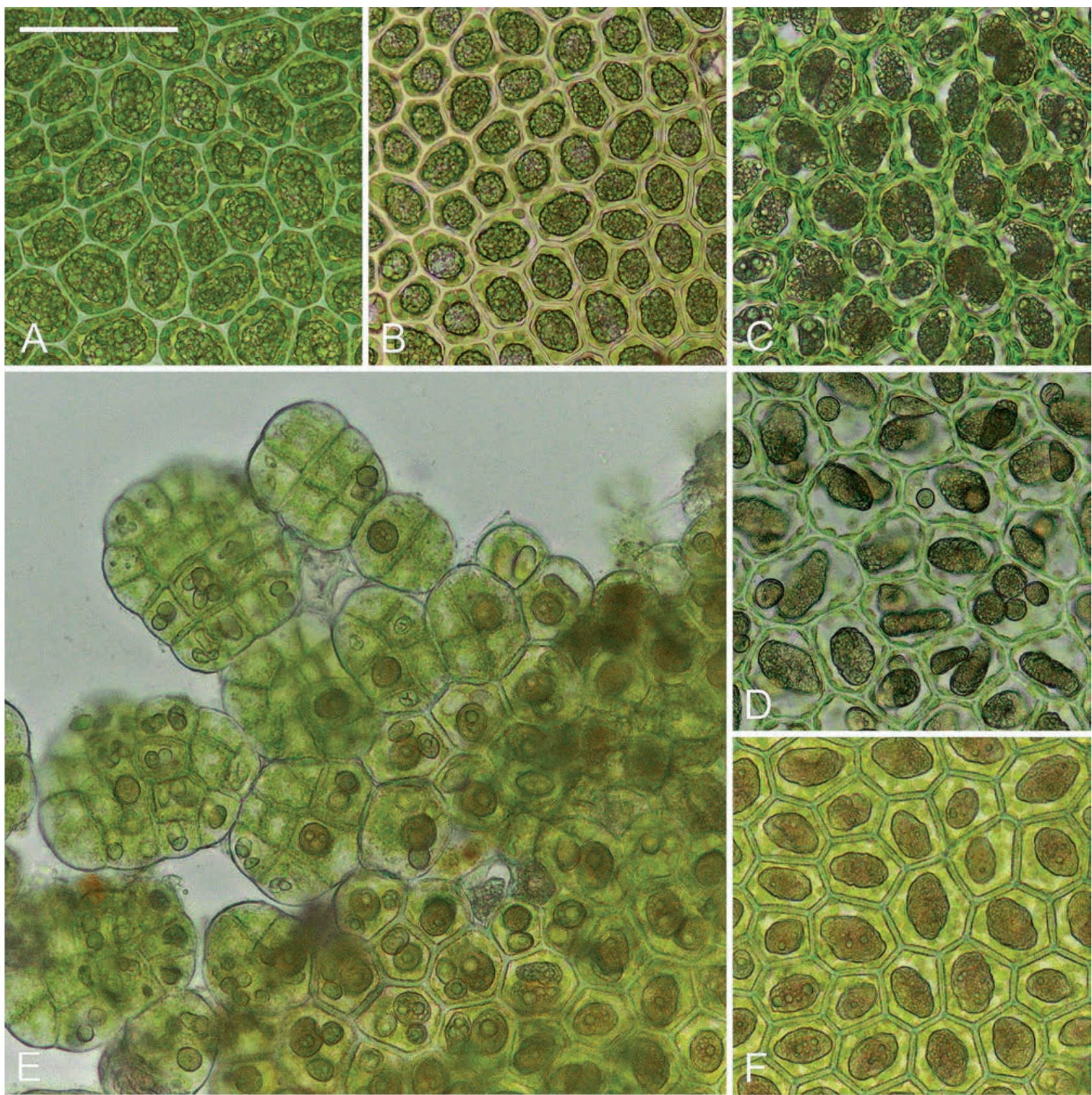

Figure 3 Oil bodies photographs: A - Radula auriculata Steph. (P-34-21-14, VBGI); B - R. japonica Gottsche ex Steph. (J-2-6-13, VBGI); C - R. obtusiloba Steph. (P-40-22-15, VBGI); D - R p prolifera Arnell (Mag-29-35-14, VBGI). $\boldsymbol{R}$. constricta Steph.: E - leaf margin with gemmae; F - cells with oil bodies (from P-35-38-14, VBGI). Scale: $100 \mu \mathrm{m}$

copper-brownish) glossy coloration (such coloration never present in $R$. obtusiloba) with dorsal leaf lobes distinctly turned to ventral side and cells in the cortex (even if only one layer of cortex is present) with cell walls distinctly thickened not only in external side, but in other sides too.

Ecology. Neutro- to acidophilic meso-hygrophyte, commonly growing over shaded and moist cliffs along watercourses and stream canyons, in all cases it avoids running water proximity. Occupying middle elevation levels in mountains, it occurs in dark coniferous forests dominated by Picea ajanensis Fisch. ex Carrière and Abies nephrolepis (Trautv. ex Maxim.) Maxim. with almost inevitable admixture by some temperate trees like coniferous Taxus cuspidata Siebold \& Zucc. and Pinus koraiensis Siebold \& Zucc. and broadleaved Acer, Fraxinus, Juglans, Phellodendron, etc. Altitudinally this species most commonly occurs between 500 and $700 \mathrm{~m}$ a.s.l., rarely starting from $350 \mathrm{~m}$ and reaching upper extremes of coniferous forest belt at $1500 \mathrm{~m}$ a.s.l. Radula auriculata forms pure patches or growing with a limited number of mainly East Asian taxa including Blepharostoma minus Horik., Lophozia lantratoviae Bakalin and Trichocoleopsis sacculata (Mitt.) S. Okamura.

Distribution. Oroboreotemperate mainly East Asian taxon reaching Sino-Himalaya in the west and, as disjunction, Pacific coast of British Columbia and southern Alas$\mathrm{ka}$ in the east. Within the Russian Far East, the species is 
restricted to middle elevations of the southernmost flanks of Sikhote-Alin mountain system, rarely occurring in system of small ranges spreading from the main Sikhote-Alin ridgeline. The northernmost locality of the species in the area treated is near $43^{\circ} 40^{\prime} \mathrm{N}$ (Fig. 4:3). Potentially, this taxon may occur in the southern Kurils and South Sakhalin Island, but despite it may be easily recognized it was not found in several attempts.

Radula brunnea Steph., Sp. Hepat. 4: 232-233, 1910.

Fig. 1: 3.

Description. Plants more or less rigid, somewhat glossy, brown to blackish brown, near shoot apices less deeply colored and sometimes greenish-yellowish, loosely attached to the substrate to ascending, $1.5-2.5 \mathrm{~mm}$ wide and 10 $30 \mathrm{~mm}$ long, rarely with normal branches, but regularly with amentulose branches. Stem brownish (brown when dry), irregularly pinnately branched producing normal branches, but with very common pinnately produced amentulose branches only $1 / 2-4 / 5$ of dorsal lobe length (thus completely covered by leaves if to look from the dorsal side); cross section of well-developed stem transversely elliptic, ca $175 \times 250 \mu \mathrm{m}, 10-13$ cells high, with slightly thickened external wall and somewhat thickened radial walls those becoming thinner inward to distinctly thin in the middle, trigones large, convex, sometimes confluent (especially so in submarginal layers), outer cells $8-13 \mu \mathrm{m}$ in diameter, inward to $25 \mu \mathrm{m}$ in diameter. Rhizoids virtually absent in our material. Leaf dorsal lobes imbricate, obliquely inserted and oriented, insertion line at dorsal side distinctly arcuate, lobe base somewhat auriculate, going far beyond stem edge, with 1-2 obtuse teeth near dorsal base each terminating by slime

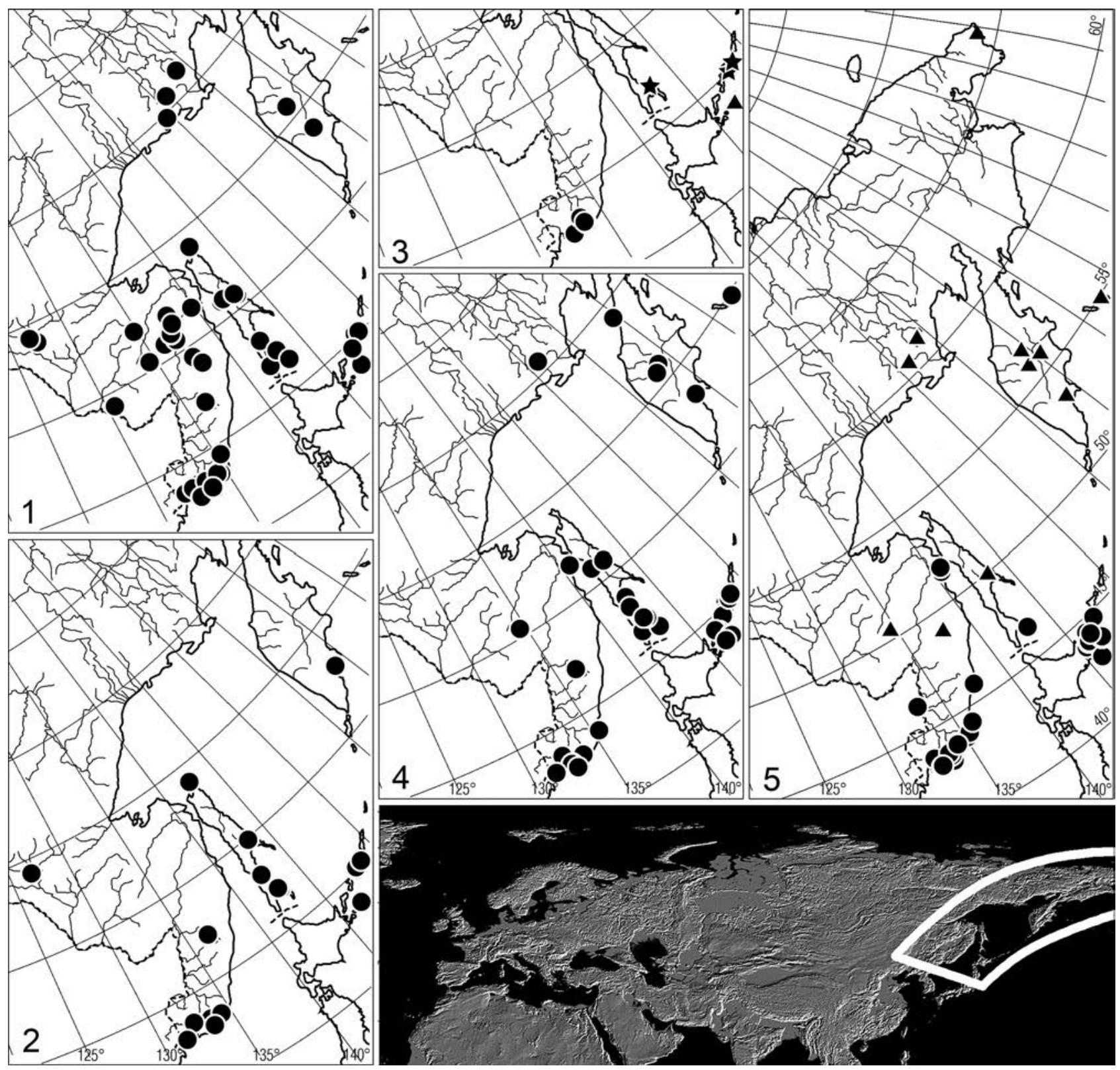

Figure 4 The distribution of Radula in the Russian Far East based on specimens examined: 1 - Radula complanata (L.) Dumort.; 2 $\boldsymbol{R}$. constricta Steph.; 3 - R. auriculata (Steph.) (circles), $\boldsymbol{R}$. brunnea Steph. (triangles), $\boldsymbol{R}$. faurieana Steph. (asterisks); $4-\boldsymbol{R}$. obtusiloba Steph.; 5 - R. japonica Gottsche ex Steph. (circles), R. prolifera Arnell (triangles) 
papilla, lobe apex rounded, distinctly turned to ventral side, when flattened in the slide obliquely-obovate to obovatefalcate, $1.2-1.8 \times 1.1-1.3 \mathrm{~mm}$. Keel nearly straight, ca $2 / 5$ of dorsal lobe length. Ventral leaf lobe nearly plane in lower half and mostly with recurved apex, when flattened rotundateellipsoidal, 0.6-1.0 $\times 0.6-0.8 \mathrm{~mm}$, obliquely inserted, with insertion line at ventral end arcuate, completely covering stem and going farther beyond stem edge, apex rounded. Cells in dorsal lobe middle isodiametric to shortly oblong, 15-30 $\times 15-20 \mu \mathrm{m}$, thin-walled, with moderate in size to large and convex trigones, cuticle smooth; cells along dorsal lobe margin 10-13 $\mu \mathrm{m}$, with external wall slightly thickened, trigones moderate in size, concave.

Comment. Very distinctive species with very restricted distribution in our area. The main characteristics of the taxon include distinctly brown to blackish brown coloration and very short amentulose branches (completely covered by dorsal lobe if to look from the dorsal side). Radula auriculata may be brownish to almost brown-green, but never as intensely brown as occurs in $\mathrm{R}$. brunnea, moreover, the former is easily differs in the absence of amentulose branches. The only taxon with amentulose branches in our area is R. prolifera that could hardly be mistaken with $\mathrm{R}$. brunnea due to distinct difference in coloration (the former is yellowish greenish) and by distribution (R. prolifera is arctic-montane taxon with generally Mega-Beringian distribution).

Ecology. Within area treated it is neutrophilic meso-hygrophyte occurring in low elevation of mountains (160-300 m a.s.l.) in very peculiar 'krumholtz' belt that may be characterized as a mosaic of dense thickets of Juniperus sargentii (A. Henry) Takeda ex Nakai and tall-forb communities (the latter are very characteristic for insular part of the extra-Arctic Russian Far East), formed under severe wind conditions. Indeed, the Shikotan Island, where the species was only collected (although found there locally abundant) is the area occupying the peculiar place among Kuril Islands due to lack of active volcanism evidences younger than the Miocene, possible insular isolation and specific features of the floristic composition. The latter may be illustrated by total absence of so widely distributed all around extra-Arctic Russian Far East Pinus pumila (Pall.) Regel, and presence some taxa occurring here and not occurring in surrounding islands, also Hokkaido. Among hepatics this is Lejeunea otiana S. Hatt. (Bakalin et al. 2009, 2019). The climate of Shikotan Island is noticeable mild, moist and with smoothened seasonal variation (varying from $-5^{\circ} \mathrm{C}$ to $+16.4^{\circ} \mathrm{C}$ with the average $+5.5^{\circ} \mathrm{C}$ : https: / / en.climate-data.org/asia/russian-federation/sakhalinoblast/malokurilsk-489817/). Low temperature variations, in the combination with severe winds, provides the conditions for development of dwarf vegetation and the mixture of different elements in the flora. These factors determined also admirable combination of Radula brunnea associates those includes both East Asian Douinia plicata (Lindb.) Konstant. \& Vilnet, Frullania appendiculata Steph., Herbertus dicranus, arcticalpine circumpolar Anthelia juratzkana (Limpr.) Trevis. and montane Diplophyllum albicans (L.) Dumort. Radula brunnea growing in pure mats or together with aforementioned associates in open moist cliff crevices in the areas commonly shrouded by fogs.
Distribution. Oroboreotemperate, mostly Japanese taxon, with one disjunction in North America. The species is distributed in Japan (Yamada 1979) only reaching the southernmost insular Russian Far East and also known from one enigmatic (probably of relict nature) occurrence in Oregon (Schofield \& Gorfrey 1979; Krayesky et al. 2018). Within the Russian Far East the species is now confirmed from Shikotan Island within the Lesser Kuril Chain (Fig.4:3). Although Radula brunnea was found in a number of localities within the Island, we guess it is hardly possible to expect it in other islands of the Kurils due to low propagation ability (it is not known with any generative structures in our area) and volcanic activity in Greater Kuril Chain. The additional historic record is available from Moneron (Kaibato) Island in southwestern vicinity of Sakhalin Island (Kamimura 1939). The latter record looks highly probable because of similarity in the condition with Shikotan Island (small island with possible effect of insularity and lowered interspecific competition and vegetation developed under severe wind conditions). Both records are probable relicts of warmer epochs (Pliocene?).

Radula complanata (L.) Dumort. Syll. Jungerm. Europ. Indig. 38, 1831 (三 Jungermannia complanata L., Sp. Pl. 1: 1133, 1753).

Fig. 1: 4, 5; 2: C, D; 5.

Description. Plants not or slightly glossy, more or less soft, yellowish greenish to deep green and bright greenyellow, loosely to closely attached to the substrate, 0.8$2.5 \mathrm{~mm}$ wide and 10-40 $\mathrm{mm}$ long. Stem greenish, brownish to yellowish brownish, soft, regularly pinnately (rarely bipinnately) branched, with some of branches easily giving the start for main and soon fertilized axis; cross section of well-developed stem transversely elliptic to rounded, ca $150-180 \times 150-200 \mu \mathrm{m}, 6-9$ cells high, external walls thickened, inward walls become thinner to thin, but with large, triangular to slightly concave or convex trigones, nearly similar in size across cross section, ca $25-30 \mu \mathrm{m}$ in diameter, cell walls greenish to greenish brownish. Rhizoids sparse to common, in short brown fascicles, from inflated area near the keel in ventral leaf lobe. Leaf dorsal lobes imbricate, subhorizontally inserted, dorsally insertion line arcuate, subhorizontally oriented, convex to slightly so, with apical part turned to ventral side of the stem, when flattened in the slide obliquely ovate to somewhat falcate, $0.5-1.6 \times 0.3-1.6 \mathrm{~mm}$, apex rounded. Keel ca $1 / 3-1 / 2$ of dorsal lobe length, convex to nearly straight. Ventral leaf lobe nearly plane to slightly convex or, in upper part, slightly concave, inflate in carinal region, subquadrate to rectangular, $0.2-0.8 \times 0.15-0.6 \mathrm{~mm}$, subhorizontally inserted, in larger plants insertion line somewhat arcuate ventrally, covering $1 / 4-1 / 3(-1 / 2)$ of stem width, apex obtuse to slightly attenuate. Cells in dorsal lobe middle subisodiametric, 5-7-gonal, 12-25 $\mu \mathrm{m}$ in diameter, thin-walled, trigones small, concave, cuticle smooth, oil bodies $1(-2)$ per cell, irregularly ellipsoidal to shortly fusiform, 12-22 $\times 7-13 \mu \mathrm{m}$, brownish-grayish; cells along dorsal lobe margin 10-20 $\mu \mathrm{m}$, external wall obscurely thickened, other walls thin, trigones small, concave. Paroicous. Gynoecia terminal on main axis or on relatively long lateral branch 
1

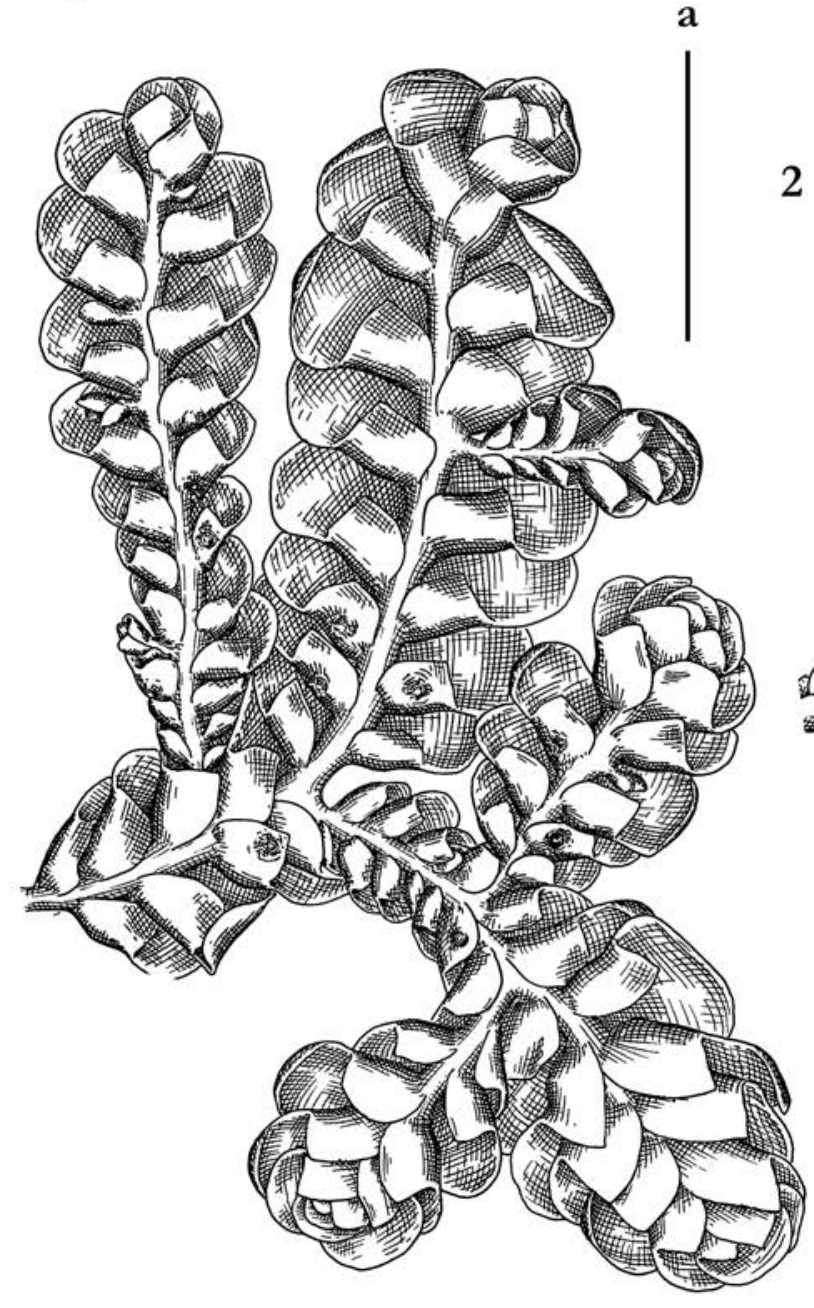

2
3

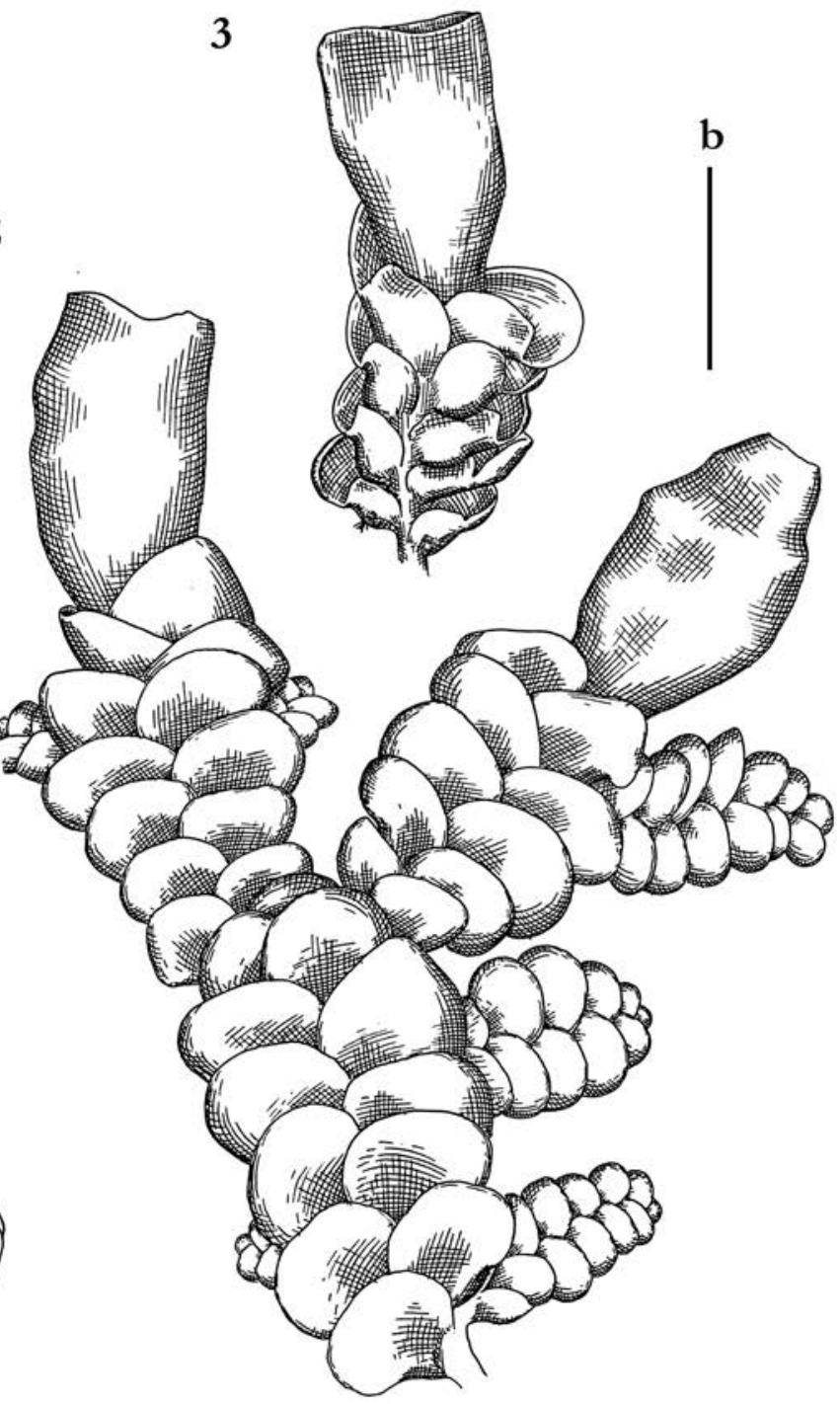

Figure 5 Radula complanata (L.) Dumort.: 1 - plant habit, ventral view; 2 - plant habit with perianths, dorsal view, 3 - plant habit with perianth, fragment, ventral view. Scales: $\mathrm{a}-1 \mathrm{~mm}$, for 1; b - $1 \mathrm{~mm}$, for 2, 3 (all from Kh-46-6-13, VBGI).

(with 5-6 pairs of leaves), with 0-2 subfloral innovations commonly becoming fertilized again, perianth narrowly obtrapezoidal to rhomboidal-obtrapezoidal (then widest in the middle), with mouth truncate and entire, 1.1-2.5 $\times$ 0.9-1.5 mm, distinctly dorsiventrally compressed, especially near the mouth where turned to ventral side (when young sporophytes inside then may be barrel-shaped). Androecia just below the perianth (sometimes including even perichaetial leaf pair), with unequal lobes and strongly convex keel, with 2-3(-4) pairs of bracts, monandrous. Seta short, slightly exerted from the perianth. Capsule ellipsoidal, $0.7-0.9 \mathrm{~mm}$ long, outer capsule cells $20-50 \times 12-25 \mu \mathrm{m}$, subquadrate to rectangular, with 2-3 nodular thickenings in each vertical wall, or with thickenings in one wall only, inner cells varying from subquadrate to sublinear, with 3-8 and more semicircular bands. Elaters bispiral (rarely trispiral in central part), ca 100-200 × 4-5 $\mu \mathrm{m}$. Spores papillose, translucent, brownish 1-celled to 6-10-celled, nearly spherical to shortly ellipsoidal, $25-45 \mu \mathrm{m}$ in diameter or shortly oblong, the germination probably started inside of capsule and then spherical several-celled entities with papillose surface are in sporophytes instead of unicellular spores. Gemmae rarely present (in our area), discoid, along dorsal side of apical leaves, (30-)50-100 and more $\mu \mathrm{m}$ in diameter.

Comment. The most widely distributed taxon in the Russian Far East, it is the southern element in the hemiarctic North, whereas the northern element in cool-temperate South of our land. The paroicous inflorescence differs it from other taxa of the genus in the Russian Far East with the exception of Radula fauriana. This species was once misidentified as Radula tokiensis Steph. from the locality in Primorsky Territory and then mentioned by Bakalin (2010). However, the latter species differs from $R$. complanata in narrow and long perianth $(2.3-2.5 \times 0.6-0.8 \mathrm{~mm})$, narrower keel-stem axis angle $\left(60^{\circ}\right.$ versus $\left.70-80^{\circ}\right)$, total absence of the gemmae and, especially, the occurrence in wet, sometimes submerged cliffs near stream (cf. Yamada 1979). In general, R. tokiensis is more southern taxon than any of our other taxa and the nearest locality we were able to observe is in the middle part of the South Korea. Other taxon with 
which $R$. complanata may be mistaken is $R$. constricta sharing with $R$. complanata size, relatively soft texture and pale yellowish greenish coloration. Both taxa are also gemmiparous, however, gemmae in $R$. complanata are rare (in the southern part of the Russian Far East less than $10 \%$ of specimens bears sparse gemmae), whereas the gemmae of R. constricta are always very abundant. The most reliable feature to distinguish both taxa are sexual conditions: $R$. constricta is dioicous, whereas $R$. complanata is uniformly paroicous (and very easily fertilized). The intergrading features and the distinctions from R. fauriana are discussed under the latter.

Ecology. Acido-tolerant to neutrophilic meso-hygrophyte. Noticeable, the species become more hygrophytic northward where occurs sometimes in much wetter habitats than in the south. Although this taxon is so widely distributed as epiphyte in middle and northern Europe and Siberia, in East Asia it occurs in such habitats much more rarely. The latter is the possible consequence of competition with congeners those extrude it from usual (in the northern Europe) habitat, with the exception of northern occurrences. Within the Russian Far East this is predominantly epilithic species observed in partly shaded to open, mesic to merely moist cliffs (including highly acidic volcanic tufa cliffs). Besides it occurs on the bark of living trees although not so commonly. Despite Radula complanata is mostly boreotemperate species there are not strict altitudinal restrictions in its distribution across the Russian Far East. In southern part (Primorsky Territory) the species occurs from 100 to $800 \mathrm{~m}$ a.s.l., northward, in Amur Region and Khabarovsk Territory the elevation varies from 150 to $1600 \mathrm{~m}$ a.s.l. (the latter is in mountain tundra belt). In insular part of the land (Sakhalin and Kurils) it occurs from near to the sea level to $800 \mathrm{~m}$ a.s.l., but mostly below $300 \mathrm{~m}$ a.s.l. Surprisingly, in Magadan Region the species growing not lower, but higher than commonly, and observed in the altitudes from 900 to $1400 \mathrm{~m}$ a.s.l. We suggest its relict occurrences there since it was met in the areas those were never (or very locally) glaciated at the Pleistocene. Like other taxa of Radula in the Russian Far East, the species is growing in pure patches, rarely occurring in association. In the southern part of the area the species may be associated with Lophocolea heterophylla (Schrad.) Dumort. over mesic cliffs, with Cololejeunea macounii (Spruce) A. Evans, Porella grandiloba Lindb., P. vernicosa Lindb. on tree trunks, rarely with Radula japonica on thin tree branches. Within boreal zone it is associated with Frullania bolanderi Austin, F. Koponenii S. Hatt., Metəgeria pubescens (Schrank) Raddi, Ptilidium pulcherrimum (Weber) Vain. on tree trunks, rarely with Plagiochila ovalifolia Mitt. near trunk bases (Sorbus). On rocky substrates may be associated with Lejeunea japonica Mitt. and Lophocolea heterophylla. In the hemiarctic, where the species observed in alpine belt only and growing only on the cliffs, it may be associated with montane or arctic-alpine taxa like Diplophyllum taxifolium (Wahlenb.) Dumort., Gymnomitrion concinnatum (Lightf.) Corda and Trilophozia quinquedentata (Huds.) Bakalin.

Distribution. Boreotemperate circumpolar taxon. The species is distributed across the Northern Hemisphere: Europe, Southwest Asia, North Africa, East and NorthEast Asia, North America and South Greenland. The report from Western Himalaya in India may be erroneous (cf. Schuster 1980). The species is common from southern part of the area to the northern boreal zone, becoming sporadic in Hemiarctic (hemiarctic forests and southern tundra zone) and vanishing to the Arctic. Radula complanata is more or less regularly occurring until $54^{\circ} \mathrm{N}$ (although quite rare in Kamchatka, even in its southern part); its northernmost latitude by specimens examined is near $61^{\circ} \mathrm{N}$, where the species is rarity (Fig. 4:1). Several localities are listed by Afonina (2000) for Chukotka Autonomous Area, where the species reaches $68^{\circ} \mathrm{N}$ (Palyavaam River). Taking into account the occurrence of the species in Magadan Region in the areas of many Beringian elements distribution, the occurrence of the taxon in Chukotka in similar conditions looks likely. We guess the distribution of Radula complanata in NorthEast Asia (Magadan Region and Chukotka) possesses relict nature due to alien phytogeographic nature of the taxon in comparison with its associates in the area. Discussing the distribution of R. complanata in Arctic Alaska, Steere (1976) regarded it as an evidence of 'Umiat syndrome' (the concept originated by Steere 1965) that, in general words, means the occurrence of southern elements in unusual Arctic environments of Umiat. We guess that if to treat this term broader than its original meaning (i.e. as the occurrence of southern elements in the North), the same phenomenon may be observed in Magadan Region and Chukotka as well.

Radula constricta Steph., Sp. Hepat. 6: 506, 1924.

Fig. 2: E, F; 3: E, F; 6.

Description. Plants not or slightly glossy, more or less soft, pale yellowish green, tightly attached to the substrate, 1.3-2.2 $\mathrm{mm}$ wide and $10-30 \mathrm{~mm}$ long. Stem greenish to brownish greenish, soft, regularly pinnately branched with the most of branches remain ill-developed, only some produce new axes and pinnately branched again; cross section of well-developed stem transversely elliptic, ca $100 \times 120-140$ $\mu \mathrm{m}, 6-7$ cells high, external wall distinctly and sometimes strongly thickened, other walls in outer layer cells somewhat thick-walled to nearly thin, walls become thinner inward, with moderate in size to large, concave to slightly convex trigones throughout, 15-20 $\mu \mathrm{m}$ in diameter. Rhizoids common, in short brownish fascicles, from inflated area near the keel in ventral lobe. Leaf dorsal lobes imbricate, subhorizontally inserted, dorsally insertion line arcuate, subhorizontally oriented, slightly convex in the middle, with apical part not or obscurely turned to ventral side, when flattened in the slide obliquely ovate to somewhat falcate, $0.7-1.0-1.5$ $\times 0.5-1.0 \mathrm{~mm}$, apex rounded to somewhat obtuse, lobe margin commonly crenulate due to gemmae production. Keel 1/3-1/2 of dorsal lobe length, slightly convex to nearly straight. Ventral leaf lobe plane to slightly convex in carinal region, subquadrate, $0.3-0.5 \times 0.3-0.4 \mathrm{~mm}$, subhorizontally inserted, insertion line in the ventralmost portion arcuate, covering $1 / 3(-1 / 2)$ of stem width, apex obtuse, rarely slightly attenuate. Cells in dorsal lobe middle subisodiametric, $15-25 \mu \mathrm{m}$ in diameter, thin-walled, trigones small to vestigial, concave, cuticle smooth; cells along dorsal lobe margin 10$15 \mu \mathrm{m}$ (larger in gemmae production area), thin-walled, with vestigial trigones. Dioicous. Gynoecia terminal on main axis, 
1

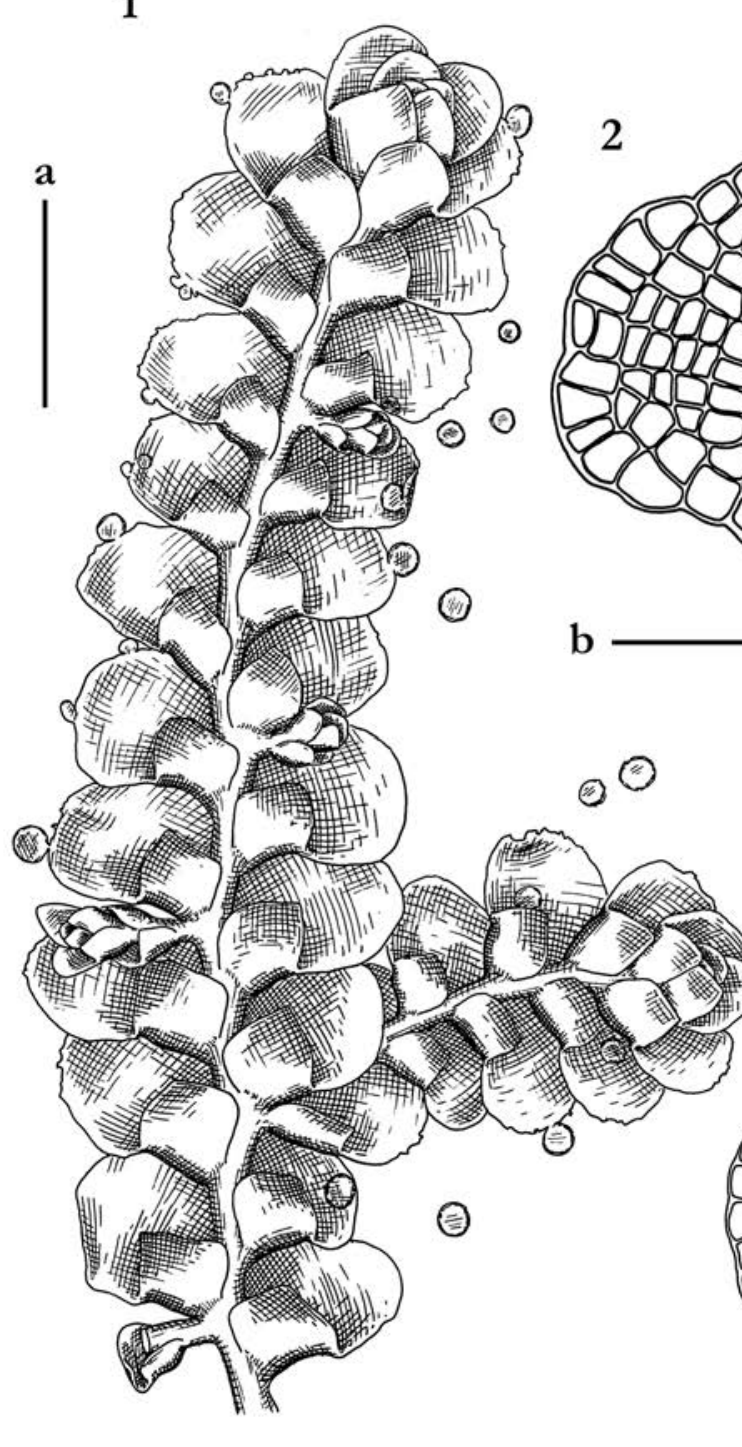

3
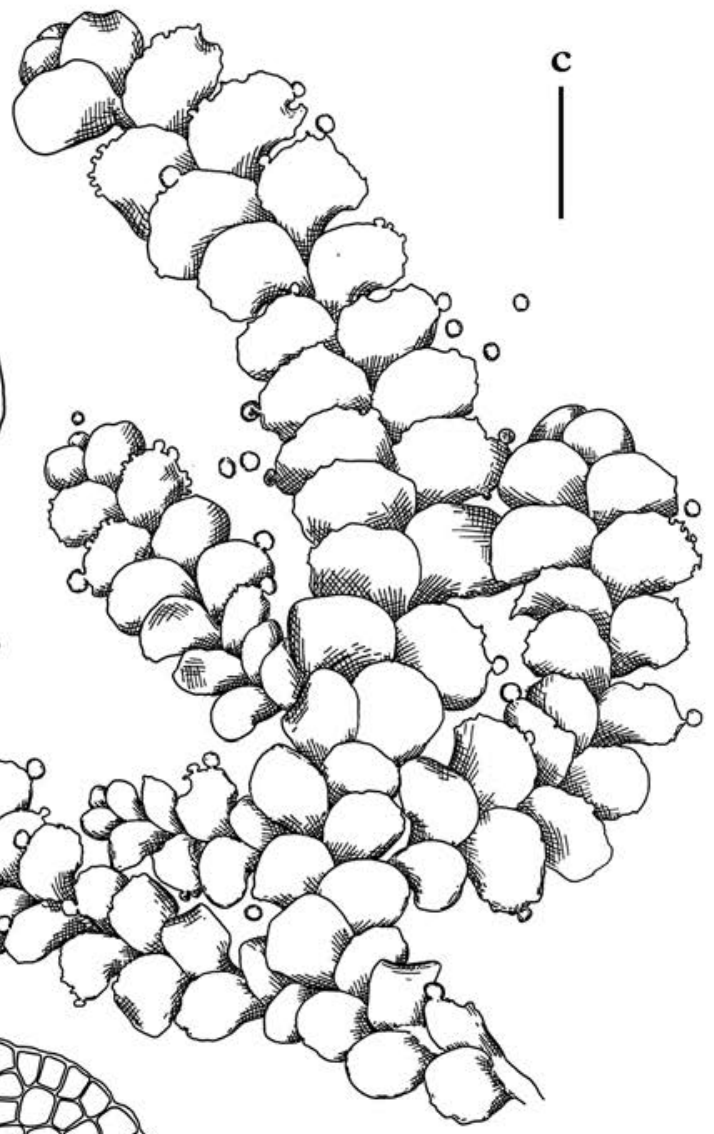

d

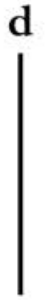

Figure 6 Radula constricta Steph.: 1 - plant habit with gemmae, ventral view; 2, 4 - gemmae; 3 - plant habit with gemmae, dorsal view. Scales: $\mathrm{a}-1 \mathrm{~mm}$, for $1 ; \mathrm{b}-100 \mu \mathrm{m}$, for $2 ; \mathrm{c}-1 \mathrm{~mm}$, for $3 ; \mathrm{d}-100 \mu \mathrm{m}$, for 4 (all from P-3-19-07, VBGI)

with one pair of bracts (bracts with ventral lobe $2 / 3-3 / 4$ of dorsal lobe in length), with 1-2 subfloral innovations, perianth obovate, slightly narrowed to truncate mouth in upper 1/3-1/4 of the length, where also somewhat turned to ventral side, ca $2.0-2.5 \times 0.9-1.1 \mathrm{~mm}$, strongly dorsiventrally compressed in upper $1 / 3-1 / 2$ of the length. Androecia spicate or not, intercalary on main axis or in lateral branches or terminal in lateral branches (branch dies after androecia), bracts commonly gemmiparous, with subequal lobes (ventral lobe $2 / 3-4 / 5$ of dorsal lobe), strongly concave, with 3-20 and more pairs of bracts. Gemmae discoid, 4 -multicellular, $30-200 \mu \mathrm{m}$ in diameter to shortly ellipsoidal, reaching $200 \times$ $150 \mu \mathrm{m}$, composed by small thin-walled cells $7-15 \mu \mathrm{m}$ in diameter, commonly profusely produced in upper half of dorsal lobe margin.

Comment. Color, size, ability to produce gemmae and texture of this species is most similar to Radula complanata among our regional taxa. Two taxa are however different in sexuality ( $R$. complanata is paroicous, whereas R. constricta is dioicous) and 'intensity' of gemmae production (very sparse and rare in the Russian Far East populations of R. complanata, versus very copious in $R$. constricta). Somewhat attenuate ventral lobe apex in $R$. constricta may also distinguish the species, but the latter feature is varying very much and two species are intergrading one to another in this parameter.

Ecology. Acidophilic meso-hygrophyte to hygrophyte growing on tree trunks and mesic rocky substrates, in the either cases sometimes covering moss or larger liverworts (like Porella) patches, and therefore epibryophytic in strict sense, rather than distinct epilithic or epixylous. Radula constricta is almost restricted to the elevations below $500 \mathrm{~m}$ a.s.l., sporadically occurring (although locally abundant) in broadleaved to mixed Manchurian and even hemiboreal coniferous forests. The species rarely occurs in other than listed communities although there are several exclusions. For instance, in East Kamchatka, where despite low elevations 
(below $100 \mathrm{~m}$ a.s.l.) the species was collected in Betula ermanii Cham. forest on mesic cliffs and wet stones along streams. In Sakhalin Island the species was found in similar habitat: shady cliffs in Betula ermanii-Pinus pumila crooked forest at $947 \mathrm{~m}$ a.s.l. In Iturup it was collected in Betula ermanii-Pinus pumila-Sasa windy community on boulders in temporary streambed. In upper elevations of Sikhote-Alin the species was once observed in the middle part of the mountain system, at elevation exceeding $1676 \mathrm{~m}$ a.s.l. in the crevice between stones on the edge of snowbed habitat in tundra belt. The species commonly growing in pure patches, either over mosses, Porella vernicosa (mainland) or P. faurieri (Steph.) S. Hatt. (insular part of the southern Far East). Rarely the species is associated with Diplophyllum taxifolium and Trilophozia quinquedentata over moist stones. In Sakhalin the species was once collected over mosses on basic rocks where it was associated with Scapania gymnostomophila Kaal. and Mesoptychia heterocolpos (Thed. ex Hartm.) L. Söderstr. \& Váňa.

Distribution. Boreotemperate, generally East Asian taxon presumable quite common in Japan, Korea and China, reaching northward hemiarctic zone in the Russian Far East (Kamchatka) and westward reaching Sino-Himalaya (India, Nepal). Within the Russian Far East, restricted to the areas in coastal mainland and insular part of the land southward of $53^{\circ} \mathrm{N}$. Sporadically occurring in Primorsky Territory (where sometimes locally abundant). Rare in Khabarovsk Territory (middle Sikhote-Alin, Sputnik Mt.) and known from one isolate locality in Amur Province (Tukuringra Range). Seems to be not rare in Sakhalin (although not known in northern half with the exception of Schmidt Peninsula in its northernmost end) and South Kurils (Iturup to Shikotan). Known from two localities in southernmost flank of East Kamchatka, where is, certainly, a rarity (Fig. 4:2).

Radula fauriana Steph., Sp. Hepat. 4: 207, 1910.

Fig. 2: G, H; 7.

Description. Plants not or slightly glossy, greenish yellowish to yellowish brownish, closely to loosely attached to the substrate, merely soft, $1.2-2.0 \mathrm{~mm}$ wide and $20-30 \mathrm{~mm}$ long, with branches of two types: 1) normal, commonly with androecia and/or gynoecia, 0.5-0.9 $\mathrm{mm}$ wide and 2) small-leaved, with leaf lobes only slightly different in size; branches of the second order are always small-leaved. Stem pale greenish brownish, regularly pinnately and sometimes bipinnately branched, merely soft; cross section of well-developed stem transversely elliptic, ca $130 \times 150-170 \mu \mathrm{m}, 7$ cells high, external wall strongly thickened, 5-6 $\mu \mathrm{m}$ thick, cells subequal in size across the cross section, 15-23 $\mu \mathrm{m}$ in diameter, walls thin, with large, commonly confluent concave to convex trigones. Rhizoids sparse to common, in short brown erect spreading fascicles, originating in inflate area near keel. Leaf dorsal lobes imbricate to contiguous, obliquely inserted, with dorsal side arcuately inserted, obliquely oriented, somewhat convex, with apical part turned to ventral side, when flattened in the slide obliquely ovate to somewhat falcate, $0.5-1.3 \times 0.4-0.8 \mathrm{~mm}$, apex rounded, margin entire or with a few short obtuse teeth near dorsal base, lobes in small-leaved branches subequal $0.2-0.3 \mathrm{~mm}$ long. Keel $1 / 4-2 / 5$ of dorsal lobe length, slightly convex.
Ventral leaf lobe plane or slightly convex in carinal region, rhomboidal with somewhat attenuate apex, 0.4-0.6 $\times$ $0.3-0.4 \mathrm{~mm}$, subhorizontally inserted, covering $1 / 4$ of stem width. Cells in dorsal lobe middle subisodiametric, 20-25 $\mu \mathrm{m}$ in diameter, 5-6-gonal, walls thin with moderate in size, slightly concave to convex trigones. Paroicous to autoicous. Gynoecia terminal on short branches, with two subfloral innovations, perianth narrowly obovate, 2.2-3.0 $\times 0.9-1.2 \mathrm{~mm}$, narrowed to truncate mouth, where only distinctly dorsiventrally compressed, in other parts cylindrical or loosely compressed, near mouth turned to ventral side. Androecia below perianth or terminal on lateral branches, with 2-4 pairs of bracts, bracts strongly inflated, with subequal lobes, never on the main axis.

Comment. The species was previously recorded for Russia based on the specimen from Sakhalin Island by Bakalin and Klimova in Ellis et al. (2017), based on sterile plants, and was never discussed for the Russian Far East with details. This account adds two more localities of the species, both are from Iturup Island of the Kurils and both contain fertile plants. The species is characterized by monoicous inflorescence, thin stem of 7 cells high only, with large trigones in the cross section and the presence of small-leaved branches. As it was noted by Yamada (1979), the species resembles Radula obtusiloba, from which differs in monoicous inflorescence (versus dioicous), distinct trigones in leaf cells and the cross section (versus trigones virtually absent in the leaves and small in the stem cross section) and the presence of small-leaves branches (versus absence). We think the confusion of $R$. fauriana is more likely with $R$. complanata that is characterized by paroicous inflorescence. However, R. complanata may be distinguished by small to very small trigones in the leaf cells and absence of small-leaved branches. Besides, if even R. complanata provides the gynoecia on lateral branches they always divided by $5-6$ and more pairs of leaves from the main axis, whereas in R. faurieana has only 3-4 pairs of leaves are present. It worth noting the gynoecium position is very strongly different in the specimens from the Russian Far East in comparison with that described by Yamada (1979) who wrote that gynoecia should be on the main axis. However, 17 years later of the cited work, in the review of Radula in Japan, Yamada (1996) provides the picture of R. fauriana bearing gynoecia on short lateral branch that is highly similar to our materials from Iturup Island.

The only record of the species (based on sterile collection) from Sakhalin Island may be questioned since plants in the specimen are characterized by leaf cells with very small trigones and small trigones in stem cross section. However, small-leaved braches are present. Moreover, that specimen was collected on coastal cliffs, not on the bark from where recorded everywhere in Japan and in Iturup. Due to color and the cell features, it may be Radula complanata, although the presence of small-leaved branches and complete absence of generative organs (very unlikely for $R$. complanata) is very distinctive.

Ecology. Acidophilic mesophyte, throughout the area virtually restricted by tree bark, although with one occurrence on rocky substrate. In Iturup Island it was collected 
on the bark of Taxus cuspidata and Betula ermanii at 20 and $400 \mathrm{~m}$ a.s.l. in central and northern part of the island. Once it was associated with Ptilidium pulcherrimum (Weber) Vain.

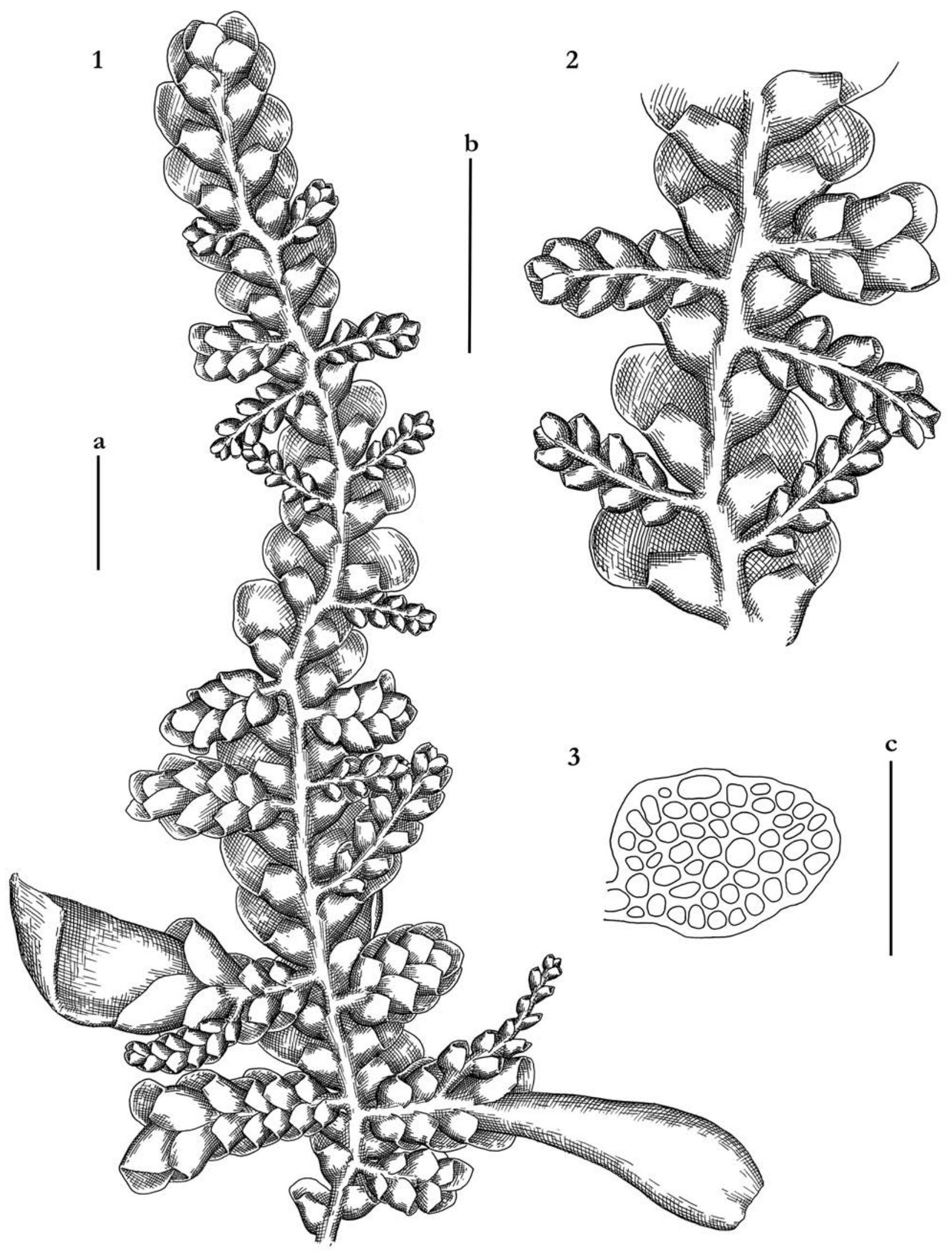

and Nipponolejeunea subalpina (Horik.) S. Hatt. The record from the southern Sakhalin is from sea coastal cliffs almost every day shrouded with the fog going from the sea. There it

Figure 7 Radula fauriana Steph.: 1 - plant habit with perianths and androecia, ventral view; 2 - plant habit, ventral view, fragment; 3 - stem cross section. Scales: $\mathrm{a}-1 \mathrm{~mm}$, for $1 ; \mathrm{b}-1 \mathrm{~mm}$, for 2 ; $\mathrm{c}-100 \mu \mathrm{m}$, for 3 (all from K-48-4-05, VBGI) 
was associated with Schistochilopsis incisa (Schrad.) Konstant. Yamada (1979) indicates this species from the elevation 100-1000 m a.s.l. in Hokkaido and from 1500-2500 m a.s.l. in Central Japan.

Distribution. Mainly Japanese orohemiboreal taxa (central and northern Japan) northward reaching southern Sakhalin and southern Kurils (where known from Iturup only) (Fig. 4: 3).

Radula japonica Gottsche ex Steph., Hedwigia 23: 152, 1884.

Fig. 3: B; 8; 9: A, B.

Description. Plants somewhat glossy, greenish, brownish to yellowish brownish, tightly attached to the substrate, 0.8-1.5 mm wide and 10-30 mm long, branches commonly
0.5-0.6 mm wide only. Stem yellowish brownish, somewhat rigid, regularly pinnately branched, branches very rarely becoming to the new main axis; the cross section of welldeveloped stem transversely elliptic, ca $80 \times 100-110 \mu \mathrm{m}$, $5-6(-7)$ cells high, external wall strongly thickened, inward cell walls unequally thickened to almost thin, trigones large, triangular to convex, rarely concave, sometimes confluent. Rhizoids common, in short brown, erect spreading fascicles, originating in inflate area near leaf keel. Leaf dorsal lobes imbricate, subhorizontally to obliquely inserted with the exception of dorsal end where insertion line arcuate, obliquely to subhorizontally oriented, slightly to strongly convex, with apical part turned to ventral side, when flattened in the slide obliquely ovate to somewhat falcate, $0.4-0.9$

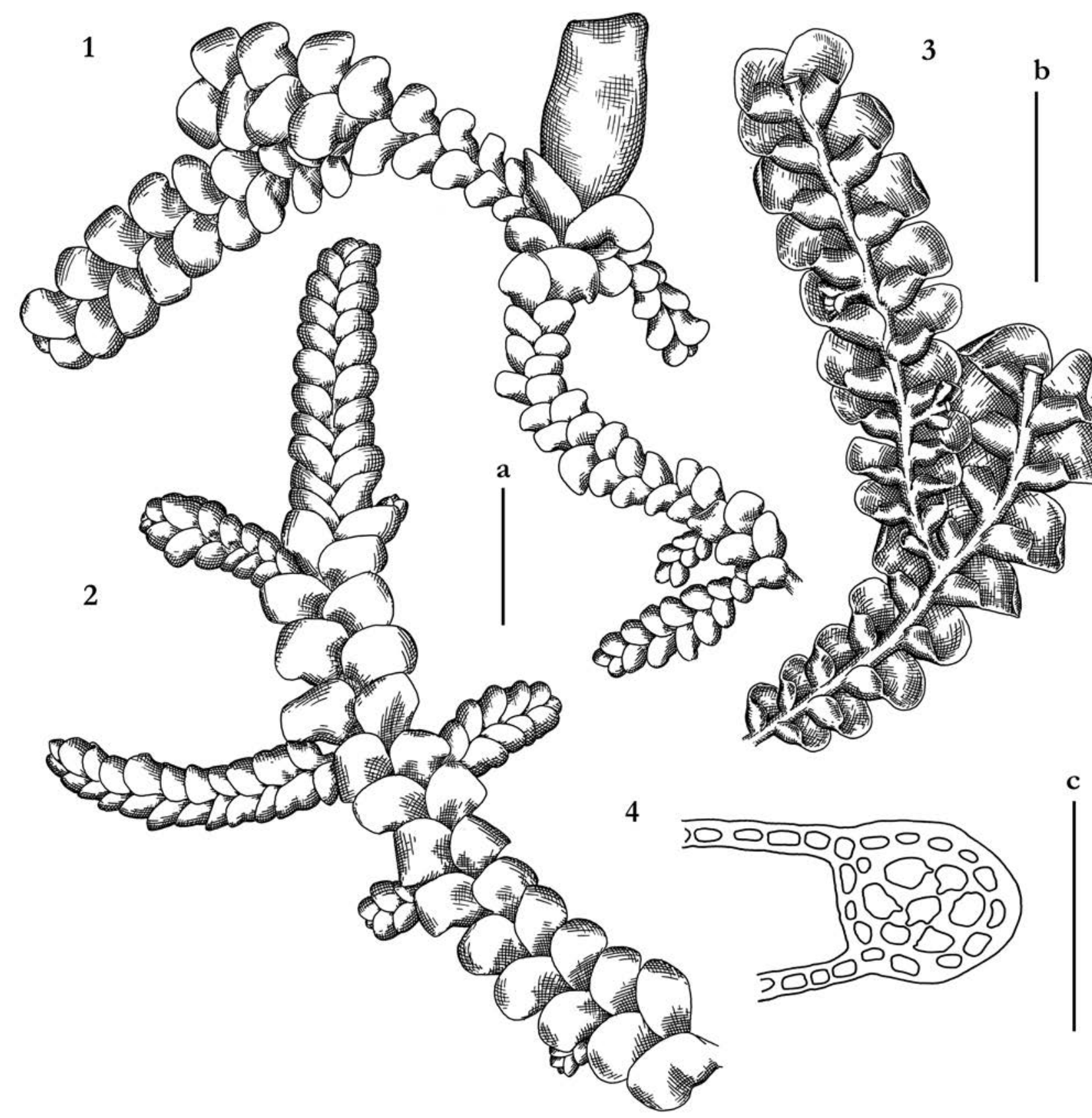

Figure 7 Radula japonica Gottsche ex Steph.: 1 - plant habit with perianth, dorsal view; 2 - plant habit with androecia, dorsal view; 3 - plant habit, ventral view; 4 - stem cross section. Scales: $\mathrm{a}-1 \mathrm{~mm}$, for 1,$2 ; \mathrm{b}-1 \mathrm{~mm}$, for 3 ; c $-100 \mu \mathrm{m}$, for 4 (1, 3, 4 from K-50-30-06; 2 from K-57-29-07, VBGI) 

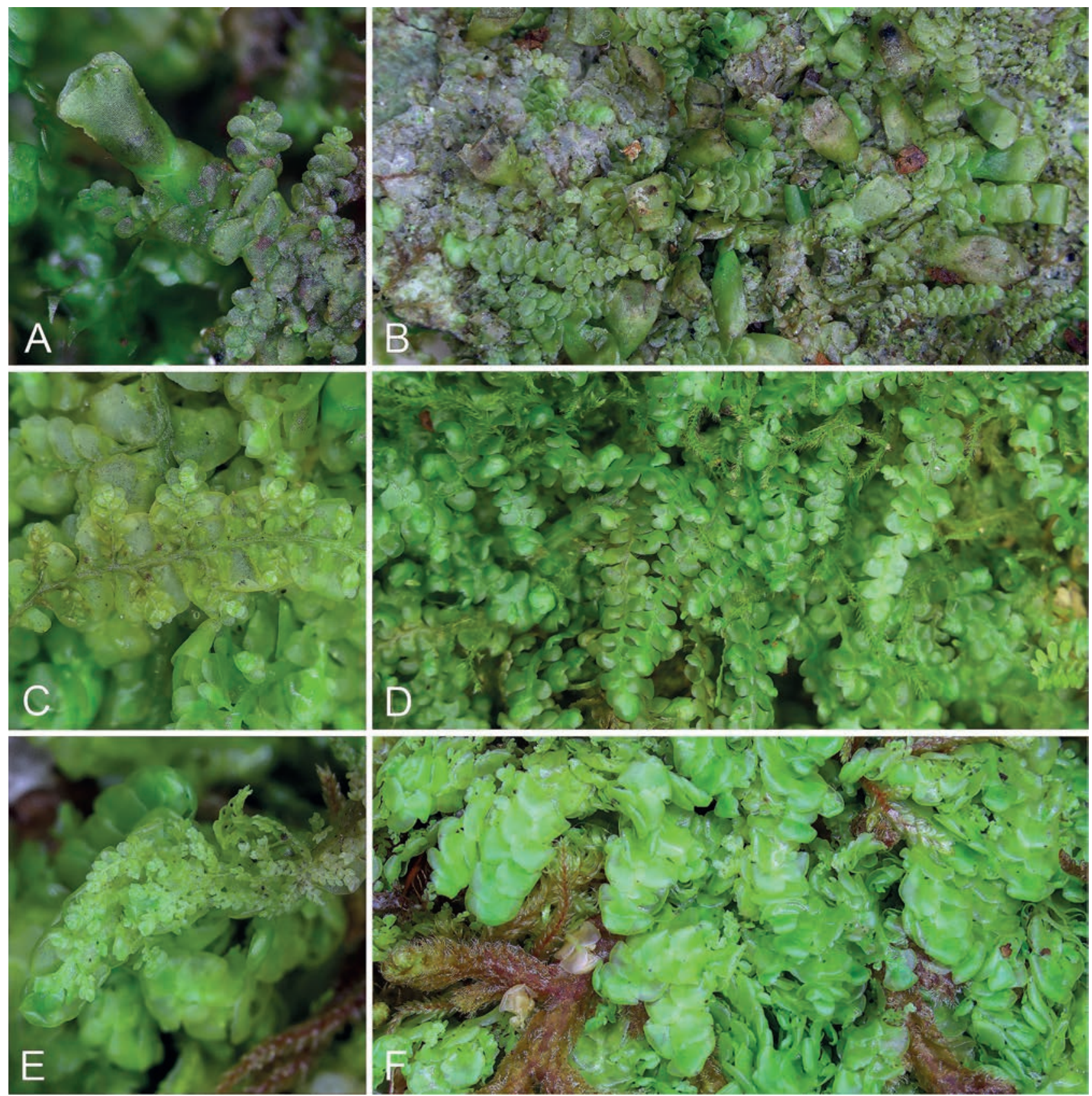

Figure 9 Radula japonica Gottsche ex Steph.: A - perianthous branch (K-32-6-18, VBGI); B - general habit with perianths (K-39-1-18, VBGI). $\boldsymbol{R}$ obtusiloba Steph.: C - branch, fragment, ventral view (K-71-37-15, VBGI); D - general habit (S-48-4-16, VBGI). $\boldsymbol{R}$. prolifera Arnell: E - branch with amentulose branches, ventral view; F - general habit (all from Kh-42-4-19, VBGI)

$\times 0.3-0.6 \mathrm{~mm}$, apex rounded. Keel ca $2 / 5$ of dorsal lobe length, slightly convex. Ventral leaf lobe plane in upper half and inflated in carinal area, subquadrate to rectangular, $0.25-0.4 \times 0.2-0.3 \mathrm{~mm}$, subhorizontally inserted, insertion line oblique in ventral side, covering $1 / 3-1 / 2$ of stem width, apex obtuse to attenuate. Cells in dorsal lobe middle subisodiametric, $10-20 \mu \mathrm{m}$ in diameter, walls thin to obscurely thickened, trigones moderate in size (rarely large), triangular to slightly convex, cuticle smooth; cells along dorsal lobe margin 7-12 $\mu \mathrm{m}$, external wall distinctly thickened, other walls obscurely thickened, trigones moderate in size to small, concave. Dioicous. Gynoecia terminal on main axis, with 1-2 subfloral innovations, perianth narrowly obovate with mouth truncate, $1.6-2.3 \times 0.6-1.0 \mathrm{~mm}$, distinctly dorsiventrally compressed, especially near the mouth where also turned to ventral side. Androecia virtually terminal in lateral branches (branch becomes depauperate and die after androecia), with 3-20 and more pairs of bracts, bracts with subequal lobes, strongly concave, divided from the main axis by 2-3 pairs of sterile leaves. Seta hardly exerted from the perianth (sometimes hidden). Capsule ellipsoidal, capsule outer cells $17-25 \times 12-18 \mu \mathrm{m}$, with $1-3$ nodular thickenings in each vertical wall. Elaters bispiral, ca 120 $150 \times 5 \mu \mathrm{m}$. Spores brownish, finely papillose, $25-50 \mu \mathrm{m}$ in diameter, 1-4-celled.

Comment. This is relatively small brownish colored species of Radula that may be mistaken in the Russian Far East with R. obtusiloba. The differentiation of the both taxa 
is easy when gynoecious material is in hand: R. japonica has gynoecia in the main axis, whereas $R$. obtusiloba has them in short lateral branches. When no gynoecious material is available, the differentiation between two taxa remains somewhat troublesome. The shoots of $\mathrm{R}$. japonica are smaller than $1.5 \mathrm{~mm}$ wide, with thinner stem of only 6 cells high, whereas stem on $R$. obtusiloba is $8-9$ cells high and the shoot size is about $2 \mathrm{~mm}$ wide. In worth to be mentioned, R. japonica is quite stable in the morphology that could not be said about much more morphologically malleable R. obtusiloba. Moreover, R. japonica is more glossy and brownish to almost brown, versus brown plants never occurred in R. obtusiloba. Although these features are of quantitative character and could be hardly definitely described. Radula japonica is also characterized by wide development of copious small-sized shoots, with the width to $0.15 \mathrm{~mm}$ wide (the feature also observed in R. obtusiloba, but not so commonly) that in the first glance may look as R. cavifolia Hampe (absent in our area) even, until the well-developed plants will be found (at least some well developed plants are always present in the mat).

The other observation was made on the coloration of the water in the drop on slide to where the plants were put in the microscope examination. All, or nearly so, species of Radula provide the coloration of the water that, although, widely vary depending on the species. The most prominent 'coloring' taxa in our flora are $R$. complanata and R. constricta (provide more or less bright yellowish green coloration of the solution). Other taxa provide brownish to yellowish brownish and greenish brownish color of much less intensity. In the sequence of decreasing of color intensity $R$. obtusiloba following to $R$. complanata and $R$. constricta, whereas $R$. japonica in the opposite end of this grade, somewhere near $R$. brunnea. This quantitative difference may also help to distinguish the taxa after some practice.

Ecology. Acidophilic mesophyte that commonly inhabits tree bark, although sometimes occurs on decaying wood and cliffs. Since Radula japonica is among the southernmost elements in our liverwort flora, the species is mostly housed by the southernmost types of vegetation present in the area. In Primorsky Territory the species is growing in broadleaved forest with certain admixture of Pinus koraiensis and Abies nephrolepis, as well as in Manchurian multidominant cool temperate forests. It rarely penetrates to Picea-Abies forest in the middle elevation of the mountains or growing in pure Quercus mongolica Fisch. ex Ledeb. stands. As an exception, it occurs in the crevices of cliffs in seacoast, or, an admirable case, in the crevices in stony field at the elevation $1500 \mathrm{~m}$ a.s.l. The altitudinal diapason covers elevations from near to sea level to $1500 \mathrm{~m}$ a.s.l., although the most of occurrences are below $500 \mathrm{~m}$ a.s.l. Northward of Primorsky Territory, in Khabarovsk (where the species is only known at the southern flank) it grows in Abies-Picea forest slightly above the sea level. In Sakhalin Island the species was found in coastal cliffs and over bark of Picea glehnii (F. Schmidt) Mast. in Picea-Abies forest. In southern Kuril Islands the species occurs in mixed (broadleaved-coniferous) hemiboreal forests (commonly on the bark of Acer, Abies, Betula, Kalopanax, Picea, Toisusu cardiophylla (Trautvetter \& Meyer) Kimura), rarely in Picea ajanensis-Betula platyphylla Sukaczev floodplain forest at the elevations below $300 \mathrm{~m}$ a.s.l. The most of associates of Radula japonica belong to temperate and boreotemperate East Asian elements in the flora: Cololejeunea ornata A. Evans, Doninia plicata, Frullania davurica, Lejeunea japonica, Metzgeria lindbergii Schiffn., Neohattoria herzogii (S. Hatt.) Kamim., Nipponolejeunea subalpina, Plagiochila ovalifolia, Porella grandiloba, $P$. vernicosa or boreotemperate and boreal circumpolar or amphi-Pacific taxa, like Metzgeria pubescens, Bazzania denudata (Torr. ex Gottsche, Lindenb. \& Nees) Trevis., Lophocolea heterophylla, Syzygiella autumnalis (DC.) K. Feldberg, Váňa, Hentschel \& Heinrichs. Among congeners, it was once found together with R. complanata.

Distribution. Temperate East Asian species distributed in Korean Peninsula and Japanese Archipelago; in the Russian Far East restricted to the southern half of Primorsky Territory, northward with disjunct occurrence in southern part Khabarovsk Territory near De-Castri Settlement (the area of presumable relict occurrences of several East Asian temperate taxa), twice recorded in the southernmost part of Sakhalin Island, relatively common and locally abundant in Kunashir Island of the southern Kurils, also sporadic in Shikotan Island and twice recorded in Iturup. The majority of occurrences of the species lie southward of $44^{\circ} \mathrm{N}$ (Fig. 4: 5).

Radula obtusiloba Steph., Bull. Herb. Boiss. 5(2): 105-106, 1897.

Fig. 3: C; 9: C, D; 10: 1, 2.

Description. Plants slightly to distinctly glossy, yellowish brownish, greenish brownish to deep green, loosely to tightly attached to the substrate, $1.5-2.4 \mathrm{~mm}$ wide and 15-40 $\mathrm{mm}$ long. Stem brownish, soft to somewhat rigid, regularly pinnately and rarely bipinnately branched, branches sometimes originating almost below each leaf, but most of them remain short and hardly exceeding dorsal lobe in length; cross section of well-developed stem transversely elliptic, ca 100-180 × 125-230 $\mu \mathrm{m}, 7-9$ cells high, external wall thickened, other cell walls in outer layer thin to obscurely thickened, $8-20 \mu \mathrm{m}$ in diameter with moderate in size, concave trigones, rarely trigones confluent in radial walls, inward cell walls become thin, with small concave trigones, 20-30 $\mu \mathrm{m}$ in diameter. Rhizoids rare, in short brownish fascicles, arisen from inflated area in ventral lobe near the keel. Leaf dorsal lobes imbricate, subhorizontally inserted, dorsally insertion line arcuate, slightly convex and subhorizontally oriented, with apical part turned to ventral side, when flattened in the slide obliquely ovate to somewhat ovate-falcate, $8-1.5 \times 0.5-1.2 \mathrm{~mm}$, apex rounded. Keel ca $1 / 3$ of dorsal lobe length, straight to slightly convex, sometimes recurved at the end. Ventral leaf lobe nearly plane in upper half and slightly inflate in carinal region, nearly rhomboidal, covering $1 / 4-1 / 3$ of stem width, $0.5-0.9$ $\times 0.4-0.7 \mathrm{~mm}$, subhorizontally inserted, ventrally insertion line curved, but not arcuate. Cells in leaf dorsal lobe middle subisodiametric, $12-23 \mu \mathrm{m}$ in diameter, walls thin, trigones small to vestigial, cuticle smooth; cells along margin 7-12 $\mu \mathrm{m}$, nearly thin-walled with vestigial trigones. Dioicous. Gynoecia terminal in short lateral branches, with 3 pairs of leaves, including bracts, if fertilized, with 2 sub- 


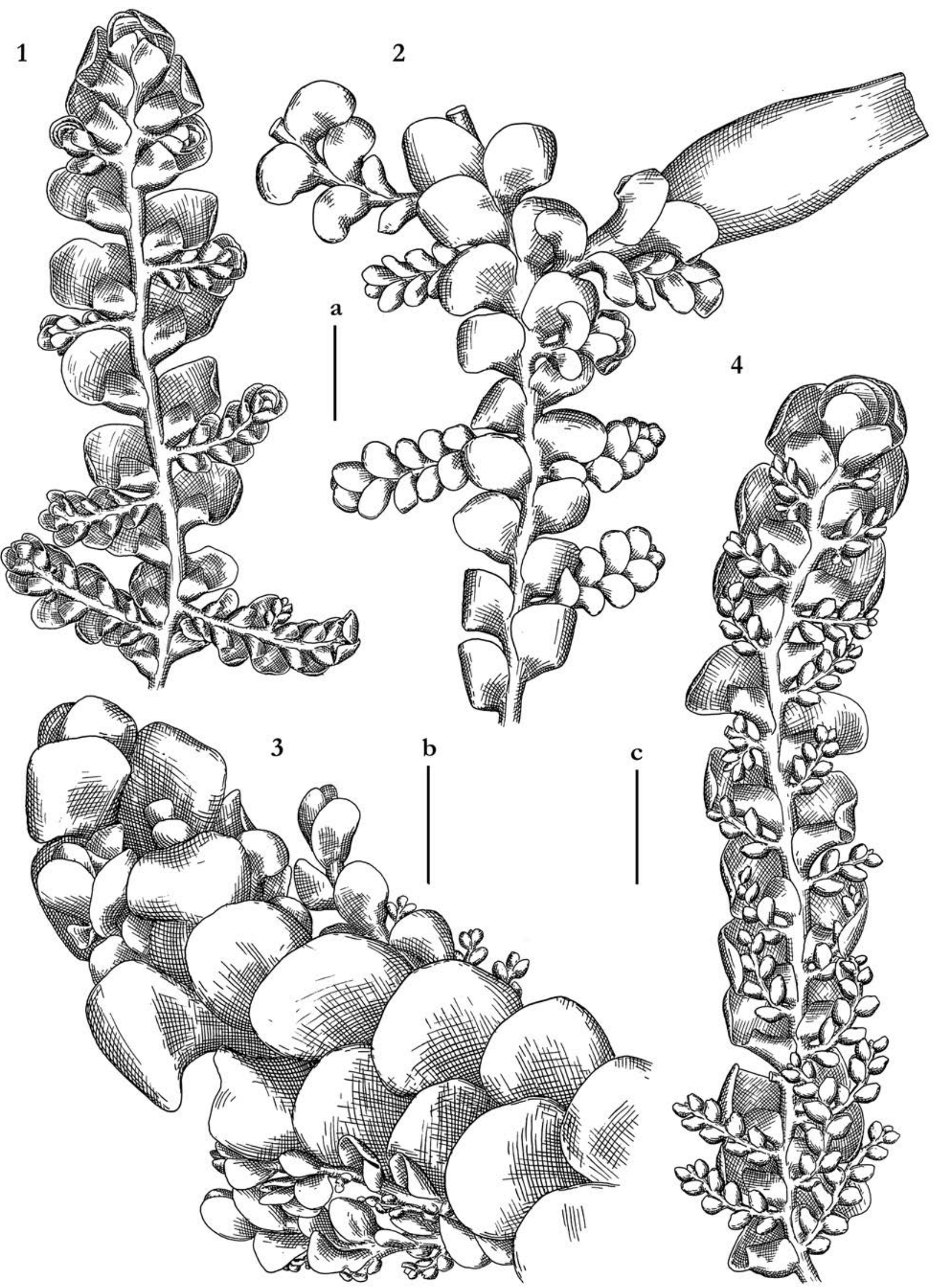

Figure 10 Radula obtusiloba Steph.: 1 - plant habit, ventral view; 2 - plant habit with perianth, dorsal view (from S-45-4-16, VBGI). R. prolifera Arnell: 3 - plant habit, dorsal view; 4 - plant habit, ventral view. Scales: a $-1 \mathrm{~mm}$, for 1, 2; b - $1 \mathrm{~mm}$, for 3; c $-1 \mathrm{~mm}$, for 4 (from Kh-40-11-13, VBGI) 
floral innovations, if not - subfloral innovations are absent, perianth nearly rhomboidal (widest slightly above the middle) to even obconical (widest below the middle) with truncate mouth, ca $3.0 \times 1.2 \mathrm{~mm}$, loosely to strongly dorsiventrally compressed, well-compressed near the mouth where also somewhat turned to ventral side. Androecia virtually terminal in lateral branches (branch becomes depauperate and dies after androecia), bracts with subequal lobes, strongly concave, with 5-15 and more pairs of bracts, divided from the main axis by 2-3 pairs of sterile leaves.

Comment. Within the Russian Far East the species is morphologically similar to Radula japonica that is discussed under the latter. The confusion also looks possible with weakly developed plants of $\mathrm{R}$. auriculata. The latter differs from R. obtusiloba in more stout brownish stem (versus greenish and merely soft) with outer 2-3 layers of cells composed by unequally to subequally thickened cell walls (versus cortex absent and cell walls in the cross section are merely thin with moderate to small, concave trigones). Once the species was observed in association with $\mathrm{R}$. complanata that, however, easily differs in more bright green-yellow color and paroicous inflorescence (with gynoecia also commonly on lateral branches). Despite more than one hundred specimens are known from the Russian Far East, many of them are with gynoecia and several are with androecia, there are no specimens with sporophytes gathered in the Russian Far East. The northernmost collections of the species from Kamchatka Territory and Magadan Region were initially identified as R. prolifera due to numerous small-leaved branches in the shoots. However, brownish dirty-green color and the presence of narrow branches with lobes of unequal size eliminate $R$. prolifera. The occurrence of the taxon in northern locations in alpine tundra environments arise again the question on identity of $\mathrm{R}$. obtusiloba subsp. polyclada (A.Evans) S.Hatt. (North-West American taxon; the subspecies status was accepted also by Söderström et al. 2016) and R. obtusiloba subsp. obtusiloba. This problem was before discussed by Hattori (1966) and Yamada (1979). Both subspecies are different in distribution (temperate East Asia versus boreal western North America) and the density of branches with small leaves (the reason of the name 'polyclada'). The specimens from North-East Asia have sparse small-leaves branches, those not so abundant as it should be in subsp. polyclada, whereas some specimens from the southern part of the Russian Far East has very copious small-leaved branches.

Ecology. Acidophilic to neutrotolerant mesophyte. The ecology of the species is somewhat similar to that of Radula japonica, although R. obtusiloba is more water-demanding. The main habitat of the taxon is the partly shaded bark of living trees; other habitats like rocky outcrops (including those near sea coast) and decaying wood are much rarer. The species is growing in mesic conditions, rarely, in coastal cliffs, reaches dry habitats or, on the contrary grows on moist stones along small streams. The species occurs from low elevation multidominant Manchurian forests, then via Picea-Abies dark coniferous forest belt to (very rarely) Betula ermanii crooked forest in Primorsky Territory. In the same region it was once found in the niche of limestone cliff, but the fine soil in the niche was probably not basic. Within Primorsky Territory the species occupies the elevations from near to the sea level to $550 \mathrm{~m}$ a.s.l., with one exceptional locality at $1200 \mathrm{~m}$ a.s.l. In Khabarovsk Territory the species was observed four times, two times on moist shaded cliffs in Picea-Abies forest at ca $550 \mathrm{~m}$ a.s.l. and once in coastal Picea-Abies forest at $100 \mathrm{~m}$ a.s.l. The fourth record is from quite unusual habitat in higher elevation of Mt. Ko (1774 m a.s.l.) in cliff crevices surrounded by mountain tundra.

In South Kurils the species growing on various types of the cliffs, including tufa rocky outcrops (also varying from semi-dry to moist), tree bark and fine soil, including that along streams. In low elevation it occurs in dark coniferous forests, Quercus-Acer forests with Sasa understory and hemiboreal mixed forest with Picea, Abies, Kalopanax, Acer, Taxus, etc. to even Pinus pumila-Duschekia fruticosa (Rupr.) Pouzar belt, where, certainly, is rarity. Along sea coast the species is sometimes observed in the cliffs shaded by dense Duschekia fruticosa thickets. The elevation range stretches from the near to sea level to 1200 and even slightly higher $\mathrm{m}$ a.s.l. In Sakhalin Island the species inhabits bedrocks and fine soil along streams, rarely observed on tree bases, once it was found in pyroclastic rocky outcrops of at least neutral reaction (if even not basic), where was associated with Scapania gymnostomophila. It occupies elevations from the sea level to $700 \mathrm{~m}$ a.s.l.

The species commonly grows in pure patches. In hemiboreal and temperate communities it may be associated with cool-temperate East Asian Lejeunea japonica, Plagiochila ovalifolia, Trichocoleopsis sacculata. Once it was found together with $R$. complanata. The associates in hemiboreal and boreal communities range from East Asian Dovinia plicata, Frullania takayuensis Steph., Metzgeria lindbergii, Porella faurieri, P. grandiloba to boreal and arcto-boreal circumpolar Blepharostoma trichophyllum (L.) Dumort. s.l., Diplophyllum taxifolium, Lophocolea heterophylla, Mesoptychia heterocolpos, Riccardia palmata (Hedw.) Carruth., Pellia neesiana (Gottsche) Limpr., Plagiochila porelloides (Torr. ex Nees) Lindenb. In unusual habitat in alpine environments in the middle Sikhote-Alin mentioned above (Mt. Ko) the species was recorded in small niche in humus covering rocks. This unusual locality provides associates uncharacteristic for the taxon: Frullania subarctica Vilnet, Borovich. \& Bakalin, Lejeunea alaskana (R.M. Schust. \& Steere) Inoue \& Steere, Mesoptychia heterocolpos, Ptilidium ciliare (L.) Hampe, Scapania crassiretis Bryhn, Sphenolobus saxicola (Schrad.) Steph. In Kamchatka Territory the species was observed in mountain tundra belt on moist open soil covering rocks, together with Mesoptychia heterocolpos, Metageria pubescens, Preissia quadrata (Scop.) Nees, Scapania cuspiduligera (Nees) Müll. Frib., Schljakovianthus quadrilobus (Lindb.) Konstant. \& Vilnet, Trilophozia quinquedentata, all of those are rather neutrophilous taxa. The records in Kamchatka lie between 820 and $1340 \mathrm{~m}$ a.s.l. The record in Magadan Region is from alpine belt where the species was collected in cliff crevices together with Frullania ignatovii Sofronova, Mamontov \& Potemkin and xeromorphic modification of Marsupella emarginata (Ehrh.) Dumort.

Distribution. (oro-?)Boreotemperate East Asian taxon distributed in Korean Peninsula and Japanese Archipelago, 
widely spreading to the north until the middle part of the Russian Far East. The subsp. polyclada occurs in Northwestern part of North America. The occurrences of Radula obtusiloba subsp. obtusiloba in the Russian Far East are at the northern limit of the taxon distribution. It is somewhat common in Primorsky Territory from its southern extremes to $45^{\circ} \mathrm{N}$, becomes rarer northward and there are only limited records in the southern part of Khabarovsk Territory. The species is abundant in the southern Kuril Islands, especially in Iturup Island, although slightly rarer in adjacent Kunashir and Shikotan. The species is not known in Urup Island adjacent northward, but this is the only result of undercollecting there and the taxon should be expected in other Kuril Islands. Within Sakhalin Island R. obtusiloba was not find in its northern part, although sparsely occurs until the middle part of the island (until Due Settlement at $50^{\circ} 50^{\prime} \mathrm{N}$ ). The occurrences of the species in North-East Asia in Kolyma Upland $\left(60^{\circ} 38^{\prime} \mathrm{N}\right)$, Kamchatka Peninsula, Commander Archipelago (Fig. 4:4) may have the relict nature or resemble distribution of $R$. obtusiloba subsp. polyclada in Alaska where the northernmost records are from "Valdez-Cordova census area", northward of $60^{\circ} \mathrm{N}$ (Söderström et al. 2015).

Radula prolifera Arnell, Ark. Bot. 13(2): 12-13, pl. 1, f. 1-2, 1913.

Fig. 3: D; 9: E, F; 10: 3,4.

Description. Plants somewhat glossy, slightly rigid, yellowish greenish, yellowish brownish to yellowish, loosely attached to the substrate to slightly ascending, 1.2-1.7 $\mathrm{mm}$ wide and 10-30 mm long, amentulose branches regular, 0.3 $0.4 \mathrm{~mm}$ wide and 1-2 mm long. Stem yellowish brownish, more or less rigid to somewhat soft, with regularly (below each leaf) produced amentulose branches, normal branches rare, rarely bipinnately branched with branches of the second order produced both from amentulose and normal branches; cross section of well-developed stem transversely elliptic to circular, $100-150 \times 120-150 \mu \mathrm{m}$, rarely to $175 \mu \mathrm{m}$ in diameter, 7-8 cells high, external wall noticeable thickened, other walls in stem cross section thin, with large to moderate in size, concave to triangle, sometimes confluent trigones, $12-24 \mu \mathrm{m}$ in diameter. Rhizoids absent in our material. Leaf dorsal lobes imbricate, obliquely inserted, dorsally insertion line arcuate, obliquely oriented, distinctly convex, with apical part commonly turned to ventral side of stem, when flattened in the slide distinctly falcate, well developed 0.7-1.2 × 0.6-0.8(-0.9) mm, apex rounded. Keel ca $1 / 3$ of dorsal lobe length, slightly convex, sometimes suddenly recurved at the end. Ventral leaf lobe slightly convex, rhomboidal, $0.45-0.7 \times 0.25-0.58 \mathrm{~mm}$ subhorizontally inserted, covering $1 / 4-1 / 3(-1 / 2)$ of stem width, apex rounded to obtuse or sometimes slightly attenuate. Amentulose branches with concave leaves ca 170-370 $\mu \mathrm{m}$ long, with subequal ventral and dorsal lobes. Cells in dorsal lobe middle shortly oblong, 20-30 × 12-20 $\mu \mathrm{m}$ to subisodiametric, $12-17 \mu \mathrm{m}$ in diameter, thin-walled, with large, concave to convex trigones, cuticle smooth; cells along dorsal lobe margin 7-20 $\mu \mathrm{m}$, external wall slightly thickened, other walls thin, trigones large, concave to convex.
Dioicous or autoicous. Gynoecia terminal on short (with 3-5 pairs of leaves, including bracts) lateral branches on the main axis, with regular amentulose branches, rarely terminal on main stem, then with 1-2 subfloral normal innovations, perianth narrowly obconical, ca 3.0-4.2 × 0.7-1.3 mm, rarely perianth shortly obovate, $2.5 \times 1.2 \mathrm{~mm}$, in upper third loosely dorsiventrally compressed and not compressed below. Androecia spicate, on branches, with 4-5 pairs of bracts, terminal (branch dies after androecial zone), presumable monandrous, stalk biseriate, $125 \mu \mathrm{m}$ long.

Comment. Commonly easily identified species due to presence of regular amentulose branches (virtually below each leaf keel) and yellowish to greenish yellowish and almost yellow pigmentation. However, the species is possible to mistake with Radula obtusiloba that sometimes reaches alpine belt in the mountains and rarely penetrate to hemiarctic zone. Two taxa are differentiable in coloration that is dirty green to green brownish in R. obtusiloba (versus yellowish coloration in $\mathrm{R}$. prolifera) and also by different character of branch leaves. Although R. obtusiloba is characterized by the presence of small-leaved branches, those only rarely become to ordinary branch, the branch leaves have distinctly different lobe sizes (versus subequal in $\mathrm{R}$. prolifera) and commonly much longer than dorsal lobe length (versus as long or slightly longer in R. prolifera). Moreover, $R$. obtusiloba in alpine belt commonly occurs in acidic stations, whereas $R$. prolifera prefers neutral to even basic substrates, occurring in mossy tundras on the percolate waters of basic reaction, as a rule. The species somewhat varies in southern extreme of the distribution in Sakhalin Island, where amentulose branches are longer and have leaves with distinctly unequal lobes in their bases, but soon becoming subequal in upper part of the branch.

Another comment should be made concerning of sexuality of the taxon. Yamada (1979) and Duda (1977) indicate monoicous (autoicous) inflorescence, whereas Schljakov (1982) indicates both dioicous and autoicous inflorescences. In our material both inflorescences are known. Moreover the perianths are not extremely rare in the species that is contrary to Schljakov (1982) who mentioned that the perianths in the North-East Asia were found only once and suggested their rarity.

Ecology. Neutrophilic meso-hygrophyte, in southern extremes of the area also basic-tolerant, probably one of the most water-depending Radula taxa in our area. The general trend in the habitat variations of the taxon from the North to the South is the replacing of moist tundras on flattened surfaces for mossy-lichen mesic mountain tundra communities on steep slopes. The southern records are from continental mainland in North Sikhote-Alin (TardokiYani Mt.) and Badzhalsky Range, where the species occurs above 1940 and $1640 \mathrm{~m}$ a.s.l. correspondingly. It forms pure mats in cliff crevices or occurring there in association with Anastrophyllum assimile (Mitt.) Steph, Blepharostoma trichophyllum s.l., Calycularia laxa Lindb. \& Arnell, Frullania subarctica, Scapania microdonta (Mitt.) Müll. Frib., Trilophozia quinquedentata. On moist cliffs it was once collected together with Marsupella emarginata. The distribution in Sakhalin Province is restricted to limestone rocky outcrops and due to this fact 
is somewhat peculiar in moisture conditions (more dry); the species is observed there at the elevations above $900 \mathrm{~m}$ a.s.l.

The species is abundant in some areas in Kamchatka (especially central part), where occurs in moist mossy tundras on flattened surfaces or on slopes and mossy edges of solifluction spots, everywhere in the sites with percolated neutral waters and above $1000 \mathrm{~m}$ a.s.l. It forms pure patches or associated with Blepharostoma trichophyllum subsp. brevirete (Bryhn \& Kaal.) R.M. Schust., Cryptocolea imbricata R.M. Schust., Diplophyllum taxifolium, Psendolophozia sudetica (Nees ex Huebener) Konstant. \& Vilnet, Trilophozia quinquedentata, as well as with worldwide rarity Sphenolobus cavifolius (H. Buch \& S.W. Arnell) Müll. Frib.

In Magadan Region the species rarely grows in pure patches, more often it is associated with Odontoschisma macounii (Austin) Underw., Plagiochila arctica Bryhn \& Kaal., Ptilidium ciliare, Scapania simmonsii Bryhn \& Kaal. It grows over moss hummocks in moss tundra in the areas of distribution of limestone and basalt outcrops, as well as with Blepharostoma trichophyllum subsp. brevirete, Trilophozia quinquedentata, Scapania simmonsii, Sphenolobus minutus on wet margins of solifluction spots, and Frullania subarctica, Lejeunea alaskana, Trilophozia quinquedentata in cliff crevices. All records in Magadan Region are from above 1000-1400 m a.s.l. In Chukotka, R. prolifera was confirmed in association with Mesoptychia heterocolpos and Tritomaria scitula (Taylor) Jørg. in wet sedge moss tundra.

Distribution. Arctic-montane, by area core MegaBeringian taxon. In the Russian Far East the species is locally abundant in North-East Asian provinces, including Chukotka Autonomous Area, Magadan Region and some areas in Kamchatka Territory. Southward becomes rare and occurs in the sites where may be suggested as relict. In the latter cases it is commonly associated with other taxa of Mega-Beringian distribution and occurs uppermost elevation levels in mountains. The southernmost report in the mainland is from the northern part of Sikhote-Alin Mts. - an area with the southernmost enclave of arcticalpine liverwort occurrence in Asia (Bakalin 2015). Slightly northward is observed in Badzhalsky Range, also in the uppermost elevations. The distribution in Sakhalin Region is restricted by one locality in East-Sakhalin Mts. - Mt. Vaida

In Kamchatka Peninsula, the species is widely distributed in alpine belt in the central part of the peninsula. Sparsely occurs in East Kamchatka (Klyuchevaskaya group of volcanoes and Pinachevsky Pass, cf. Bakalin \& Klimova 2018). The record from Commander Archipelago (K-54-12-04, VBGI) is doubtful, because based on one specimen with three tiny shoots with a few amentulose branches. Within Magadan Region Radula prolifera is merely common in alpine belt (Fig. 4: 5). Due to literature records (Afonina 2000) very common (that is, indeed, highly likely!) in Chukotka Autonomous Area, starting from the high Arctic (Wrangell Island) and then southward and eastward to Lawrence Bay in $171^{\circ} \mathrm{W}$. Logically, the species is quite common on opposite side of Bering Strait in Alaska (Söderström et al. 2015).

\section{Excluded taxa}

Radula tokiensis Steph. - the record of this species in Bakalin (2010) is based on the erroneous identification of R. complanata.
Radula lindenbergiana Gottsche ex C.Hartm. - the records of this species by Gambaryan (1984), Cherdantseva \& Gambaryan (1986) and Kitagawa (1965) from the southern part of the Russian Far East are likely belonging to R. constricta as it was shown by Yamada (1986).

\section{PHYTOGEOGRAPHIC DISCUSSION}

Nine species of Radula are recorded in Russia (Konstantinova et al. 2009, with supplement from the present account). Radula lindenbergiana, mainly European taxon, is restricted in Russia to European part of the country, with isolated locality in South Siberia (the identity may be questioned). Two more species occur both inside and outside of the Russian Far East in the country: Mega-Beringian R. prolifera and circumpolar R. complanata. Therefore, 6 taxa occur in Russia in the Russian Far East only. Eight recorded taxa is quite high number in comparison with other macroregions of Russia, although this number is lesser than it is known e.g. in Japan, where 23 species are known (Yamada 1996). Chinese flora counts 34 taxa of Radula (some records are dubious, like $R$. lindenbergiana that should be $R$. constricta also recorded in the same list, Piippo 1990). The diversity within China increases southward and reaches maximum in Taiwan Island that houses 21 species, 13 of which belong to the group of taxa with Indomalaysian distribution (Yamada \& Inoue 1988). Contrary to the south, the North-East China (Heilongjiang, Jilin and Liaoning Provinces) houses 4 taxa of Radula only (Piippo 1990) that is certainly too low number and may be explained by poor knowledge on this genus there. The diversity of Radula in North America (north of Mexico) counts 15 taxa (Krayesky 2018), with six of them known in its western part (Hong et al. 1990). The latter is quite comparable with the number obtained for the Russian Far East.

Three of eight taxa recorded in the Russian Far East (Radula brunnea, R. auriculata and R. fauriana) are restricted to the southernmost flank of the area. Radula japonica and R. constricta distributed much broader and slightly pass $50^{\circ} \mathrm{N}$ going northward. R. obtusiloba is characterized even broader distribution and pass $60^{\circ} \mathrm{N}$. All listed species possess area core in East Asia, besides R. brunnea is known from one locality in Oregon (Schofield \& Godfrey 1979, Hong et al. 1990), R. auriculata occurred in British Columbia and Alaska (Krayesky 2018) and R. obtusiloba subsp. obtusiloba is replaced in western coast of North America (Alaska, British Columbia, Washington) by morphologically very similar subsp. polyclada (indeed we doubt the differences between these two names are of subspecies rank). Iwatsuki (1972) argued that phytogeographical similarity between 'East-East' disjunction type (i.e. East Asian - Eastern North American) are evident in temperate taxa, whereas the relationships in 'East-West' disjunction (i.e. East Asian - Western North America) are characteristic for boreal taxa. In the present situation, we may accept the latter point of view with some reservations. All Radula known in the Russian Far East and possessing such distribution type belong to boreotemperate to oroboreotemperate flora element.

Therefore, the relatively high taxonomic diversity of $\mathrm{R} a$ dula in the Russian Far East may reflect, in its large part, 
the wide penetration of mainly East Asian Radula to the northern fringes of East-Asian floristic Province and in the adjacent areas of southern part of Pacific sector of Circumboreal floristic Region. The same phenomenon is characteristic for distribution of many other predominantly 'southern' families (Porellaceae, Lejeuenaceae, Jubulaceae, Frullaniaceae) and is responsible for the prominent specificity of the Russian Far East liverwort flora in comparison with other Russian macro-regions.

\section{ACKNOWLEDGEMENTS}

Authors are deeply indebted to Mr. Matvei Bakalin for providing line drawings for the present paper, Mr. Daniil Bakalin for software preparation for map making up. The work was partially supported by the grant from Russian Foundation for the Basic Researches (17-04-00018).

\section{LITERATURE CITED}

Afonina, O.M. 2000. Bryoflora of Chukotka. Doctoral dissertation. Saint Petersburg, 400 pp. (In Russian) [Афонина O.M. 2000. Бриофмора Чукотки. Аиссертация ... Аоктора биол. наук. Санкт-Петербург: 400 с.].

Bakalin, V.A. 2010. The distribution of bryophytes in the Russian Far East. Part. 1. Hepatics. Izdatel'stvo Dal'nevostochnogo Federal'nogo Universiteta, Vladivostok, 175 pp. (in Russian and English) [Бакалин B.A. 2010. Распространение мохообразных на Аальнем Востоке России. Часть 1. Печеночники. ВАадивосток: ИзАательство Аальневосточного Федерального университета, 175 с.].

Bakalin, V.A. 2015. Tardoki-Yani Range (North Sikhote-Alin, Pacific Russia) - the largest southern refugium of arcticalpine liverwort flora in East Asia. Arctoa 24:314-326.

Bakalin, V.A. \& K.G. Klimova 2018. Liverwort flora of Nature Park "Nalychevo" (Kamchatka Peninsula). V.L. Ko marov Memorial Lectures 65:29-54 (In Russian with English summary). [Бакалин В.А., КАимова К.Г. 2018. ФАора печеночников (Нераticae) природного парка «Налычево» (полуостров Камчатка) // Комаровские чтения. Вып. 65. С. 29-54].

Bakalin, V., V. Fedosov, O. Pisarenko \& E. Borovichev 2019. The bryophyte flora of northern Iturup (north-west Pacific): between the circumboreal and East Asian floristic regions. Journal of Bryology 41(3):249-262.

Bakalin, V.A., V.Ya. Cherdantseva, M.S. Ignatov, E.A. Ignatova \& T.I. Nyushko 2009. Bryophyte flora of the South Kuril Islands (East Asia). Arctoa 18:69-114.

Cherdantseva, V.Ya. \& S.K Gambaryan 1986. Bryophytes. In: Flora and vegetation of Bolshekhekhtsirsky Nature Reserve (Khabarovsk Territory), (Azbukina Z.M., Melnikova A.B., Baburin A.A. et al.), pp. 79-101, Dal'nevostochnyi Nauchnyi Tsentr akademii nauk SSSR, Vladivostok (in Russian). [Черданцева В.Я., Гамб̄арян С.К. 1986. Мохообразные // Фцора и растительность Большехехцирского заповедника (Хабаровский край) / Азбукина 3.М., Мельникова А.Б., Бабурин А.А. и Ар. Владивосток: АВНЦ АН СССР. С. 79-101].

Devos, N., M.A.M. Renner, S.R, Gradstein, A.J. Shaw \& A. Vanderpoorten 2011. Molecular data challenge traditional subgeneric divisions in the leafy liverwort Radula. Taxon 60(6):1623-1632.

Duda, J. 1977. Radula prolifera H. Arn. mit Perianthien. Journal of Bryology 9(4):505-507.
Ellis, L.T., M. Alataș, M. Aleffi, A. Alegro, V. Šegota, S. Ozimec, N. Vuković, N. Koletić, D. Prlić, M. Bontek, A.K. Asthana, D. Gupta, V. Sahu, K.K. Rawat, V.A. Bakalin, K.G. Klimova, K. Baráth, L. N. Beldiman, J. Csiky, J. Deme, D. Kovács, M.J. Cano, J. Guerra, I.V. Czernyadjeva, M.V. Dulin, P. Erzberger, T. Ezer, V.E. Fedosov, S. Fontinha, M. Sim-Sim, C. A. Garcia, A. Martins, I. Granzowde la Cerda, L. Sáez, K. Hassel, H. Weibull, N.G. Hodgetts, M. Infante, P. Heras, T. Kiebacher, J. Kučera, M. Lebouvier, R. Ochyra, M. Ören, B. Papp, S. J. Park, B.-Y. Sun, V. Plášek, S. Poponessi, R. Venanzoni, D. Purger, F. Reis, M. Singila, A. Stebel, S. Ştefănuţ, G. Uyar, G. Vončina, M.J. Wigginton, K.-T. Yong, M. S. Chan \& Y.-J. Yoon 2017. New national and regional bryophyte records, 52. Journal of Bryology 39(2):285-304.

Frey, W. \& M. Stech 2009. Marchantiophyta, Bryophyta, Anthocerotophyta. In: Syllabus of Plant Families. Adolf Engler's Syllabus der Pflanzenfamilien. 13th edition, Part 3. Bryophytes and seedless vascular plants, (W. Frey, ed.), pp. 1-257, Gebrüder Borntraeger, Berlin, Stuttgart.

Gambaryan, S.K. 1984. On the flora of hepatics of high mountains and spurs of Southern Sikhote-Alin. In: Systematic-floristic research of cryptogams of Far East, (Czerdantseva, V.Ya. \& al., eds), Dal'nevostochnyi Nauchnyi Tsentr akademii nauk SSSR, Vladivostok. ГГамб̄арян С.К. О флоре печеночных мхов высокогорий и отрогов южного Сихотэ-А^иня / / Систематико-флористические исследования споровых растений Аальнего Востока / пол реА. В.Я. ЧерАанцевой и Ар. ВАадивосток: АВНЦ AH CCCP. C. 54-69].

Hattori, S. 1966. Hepaticae and anthocerotae of Mt. Chokai, northern Japan. Journal of the Hattori Botanical Laboratory 29: 267-278.

Hong, W.S., D. Trexler \& K. Flanders 1990. The family Radulaceae in North America west of the hundredth meridian. Lindbergia 16:37-43.

Iwatsuki, Z. 1972. Distribution of bryophytes common to Japan and the United States. In: Floristics and paleofloristics of Asia and Eastern North America, (A. Graham, ed.), pp. 107-137, Elsevier.

Kamimura, M. 1939. Contribution to the Bryological Flora of the Island of Kaibato (Todomoshiri). Japanese Journal of Botany 15:727-734.

Kitagawa, N. 1965. Hepaticae of Sakhalin. Acta Phytotaxonomica et Geobotanica 19(4-6):146-152.

Korotkevich, L.S. 1952. Some new data on the hepatics flora of the Russian Far East. Botanicheskie Materialy Otdela Sporovyh Rastenii 8:188-196 (in Russian) [Короткевич A.C. 1952. Некоторые новые Аанные к Аальневосточной флоре печеночных мхов / / Ботанические материалы отде $а$ споровых растений. Т.8. С. 188-196].

Krayesky, D.M., L. Leonardi, J.G. Chmielewski 2018. Radulaceae. In: Bryophyte Flora of North America, Provisional Publication. Missouri Botanical Garden. Available from: http://www.mobot.org/plantscience/bfna/V3/ Radulaceae.htm . Last accessed 07 November 2019.

Lindberg, S.O. 1872. Contributio ad floram cryptogamam Asiae boreali-orientalis. Acta Societatis Scientiarum Fennicae 10:223-280.

Piippo, S. 1990. Annotated catalogue of Chinese Hepaticae and Anthocerotae. Journal of the Hattori Botanical Laboratory 68:1-192.

Schljakov, R.N. 1982. Hepatics of the North USSR, vol. 5. Nauka, Leningrad, 220 pp. (in Russian) ШШАков P.H. 1982. 
Печеночные мхи Севера СССР. А.: Наука. Т. 5. 220 с.].

Schofield, W.B. \& G.A. Godfrey 1979. Radula brunnea Steph. from Western North America. Journal of the Hattori Botanical Laboratory 46:285-288.

Schuster, R.M. 1980. The Hepaticae and Anthocerotae of North America East of the Hundredth Meridian, vol. 4. Columbia University Press, New York and Guildford, Surrey, 880 pp.

Söderström, L., A. Hagborg \& M.J. von Konrat 2015. Liverworts from the largest of the United States: a checklist for mainland Alaska. Arctoa 24:327-361.

Söderström, L., A. Hagborg, M. von Konrat, S. BartholomewBegan, D. Bell, L. Briscoe, E. Brown, D.C. Cargill, D.P. Costa, B.J. Crandall-Stotler, E.D. Cooper, G. Dauphin, J.J. Engel, K. Feldberg, D. Glenny, S.R. Gradstein, X. He, J. Heinrichs, J. Hentschel, A.L. Ilkiu-Borges, T. Katagiri, N.A. Konstantinova, J. Larrain, D.G. Long, M. Nebel, T.
Pócs, F. Felisa Puche, E. Reiner-Drehwald, M.A.M. Renner, A. Sass-Gyarmati, A. Schäfer-Verwimp, J.G.S. Moragues, R.E. Stotler, P. Sukkharak, B.M. Thiers, J. Uribe, J. Váňa, J.C. Villarreal, M. Wigginton, L. Zhang \& R.-L. Zhu 2016. World checklist of hornworts and liverworts. PhytoKeys 59:1-828.

Yamada, K. 1979. A revision of Asian taxa of Radula, Hepaticae. Journal of the Hattori Botanical Laboratory 45:201-322.

Yamada, K. 1986. Notes on Radula (Hepaticae) from the Primorye territory in Eastern USSR. Proceedings of Bryological Society of Japan 4(4):66-67.

Yamada, K. 1996. Species of the genus Radula (Hepaticae) in Japan. Natural Environmental Science Research 9:63-96.

Yamada, K. \& H. Inoue 1988. Studies on Taiwan Hepaticae VII. Radulaceae. Bulletin of the National Science Museum, Ser. B (Botany) 14(2):41-51. 